\title{
$\bullet \cdot r$
}

\section{البروفيل الاتفعالي والتوجه التنافسي لاى لاعبي الكار اتيه}

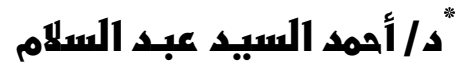

مقدمة ومشكثة البحث:

يعرف علم نفس الرياضة sport psychology بانه العلم الذى يدرس سلوك الانسان

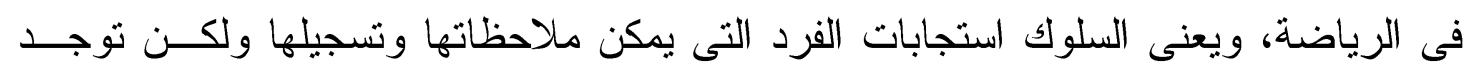

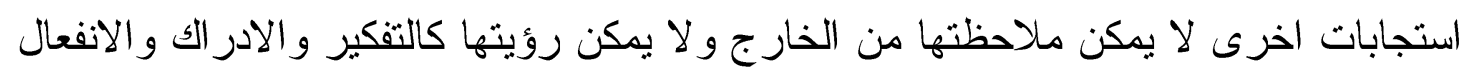

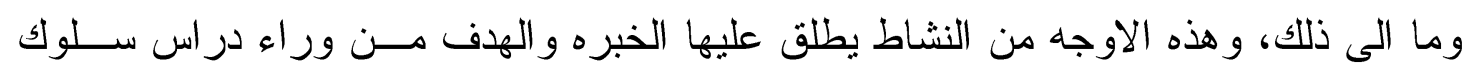

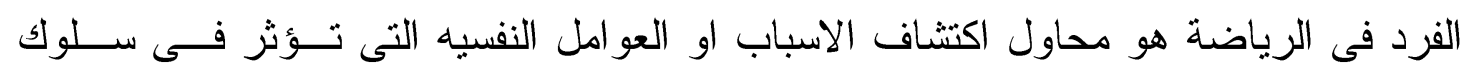

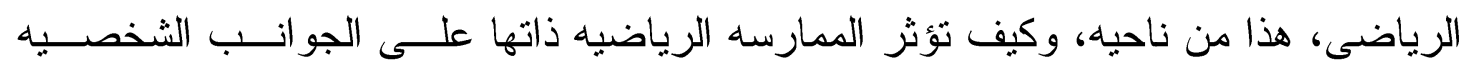

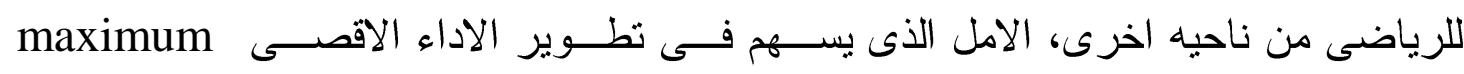
performance و الدافعيه، العنف، القياده، ديناميكيه الجماعه، افكار ومشاعر الرياضيين و العديد من الابعـاد

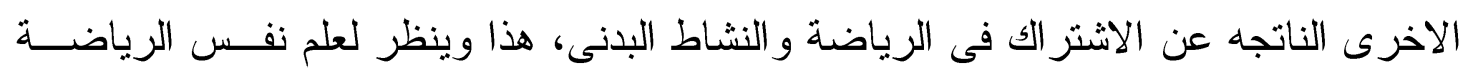

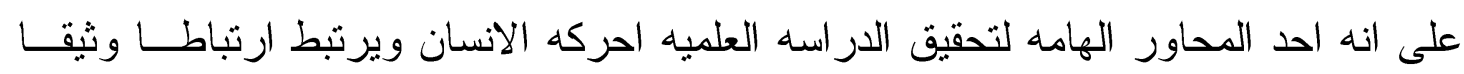

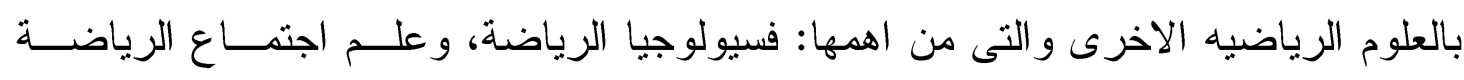

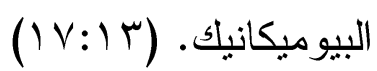

ويؤكد محمد علاوى (r . . r م) الى ان الرياضيين اصحاب المستو ايات العليا بتقاربون

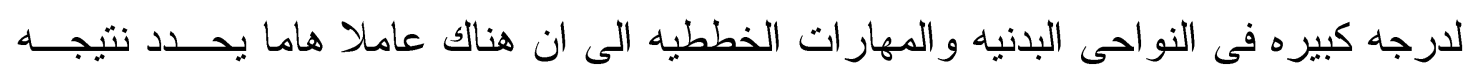

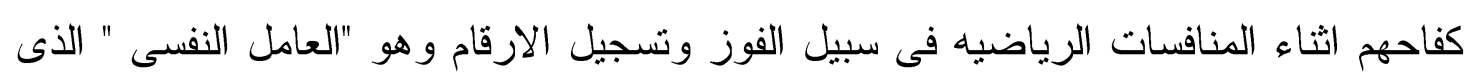

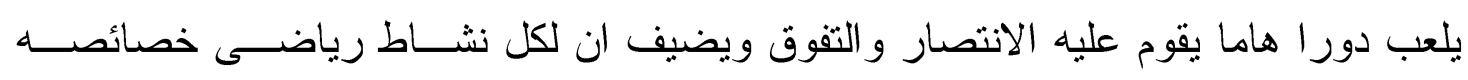

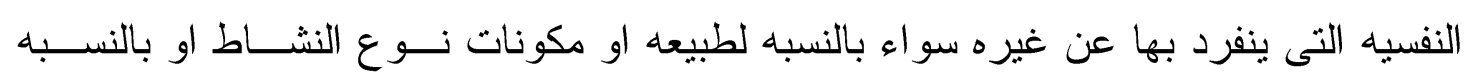
لطبيعه المهار ات الحركيه او القدرات الخططيه او بالنسبه لما ينبغى ان يتميز به الرياضى من بن

سمات نفسيه معينه.(2 (1) (1)

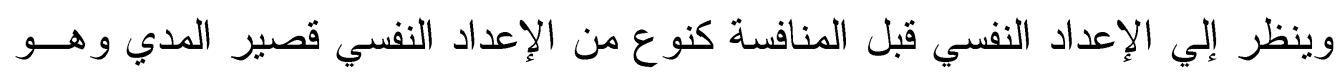
عادة يبدأ قبل المنافسة بيومين ولا يتجاوز أسبوعاً وتمثل هذه الأيام القلية والتي تسبق المنافسة وخاصة اليومين الأخيرين أهمية كبيرة فى البرنامج التدريبي وخاصة من الناحية النفسية لذلك ليس من المستغرب أن يطلق عليها بعض المتخصصين فى الإعداد النفسي للرياضيين فتـرة

* مدرس دكتور بقسم نظريات ونظبيقات رياضات المناز لات كلية التزبية الرياضية للبنين جامعة بنها مجلة أسيوط لعلوم وفنوز التربية الرياضية 


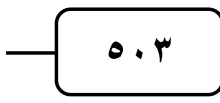

الإعداد الحرجة حيث أنه من الضروري أن يكون اللاعب فى أفضل حالاته البدنية والانفعالية

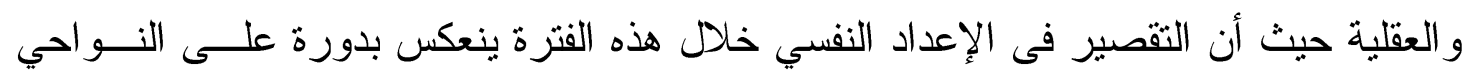
الأخري سواء كانت بدنية أو مهارية وأنه من الأهمية بمكان أن تشهد هذه الفترة أفضل حالات

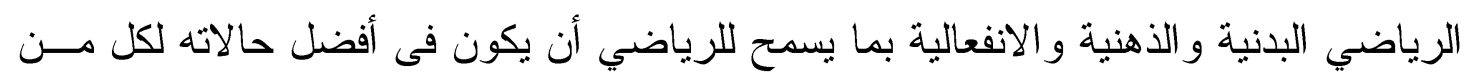
هذه الجو انب الثالثة ويعقب ذلك من خلال فهم كل من خصائص الــدورة البدنيــة و الذهنبـــة

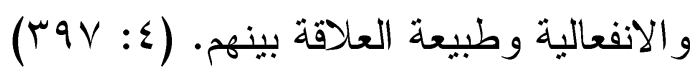

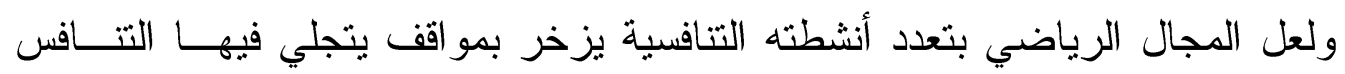

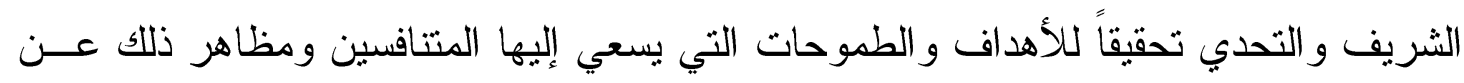
طريق تسجيل الأهداف أو الأرقام أو الارتفاع أو المسافة وكل ذلك يعتمد علـى مــدي إدر الك

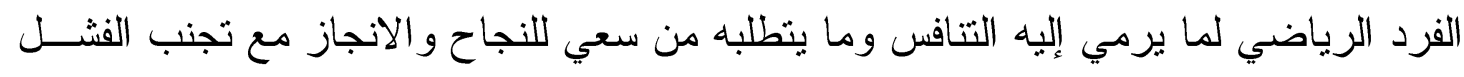

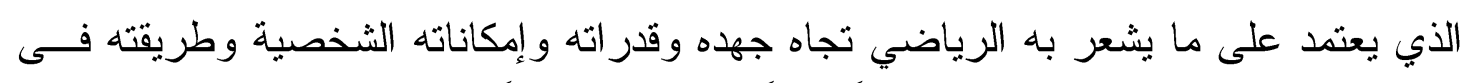
تحديد هدفه المستقبلي فالفرد ليس مؤدياً سلبياً للنشاط ومشاركاً فى التتافس فحسب بل هو دائم

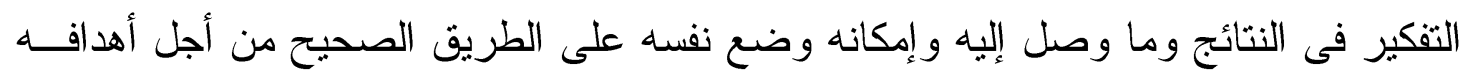

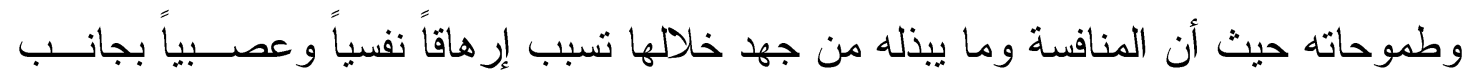
التأثير على الحالة البدنية الأمر الذي يلزم أن يكون الفرد الرياضي على درجة عالية من حسن

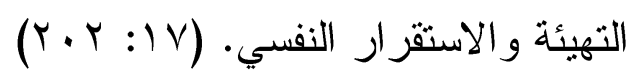

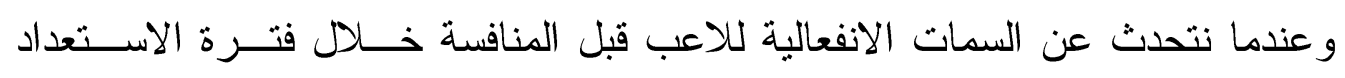
الحرجة فإن هناك عاملين يؤثران فى استعداد اللاعب ومن ثم مستوي أدائه ويرتبط العامـلـل

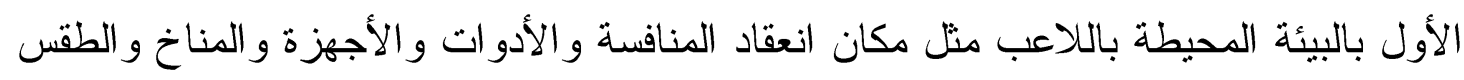

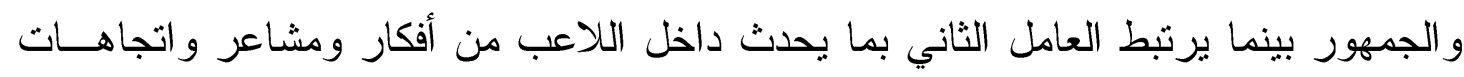

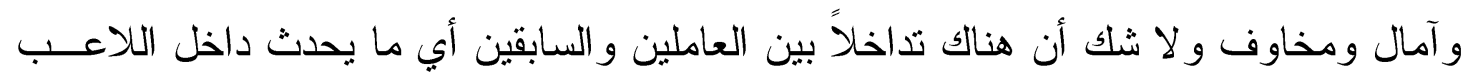

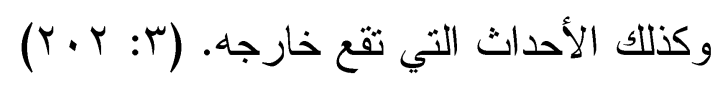

وحيث تعتبر در اسة سمات الشخصية للرياضيين واحدة من أكثر موضوعات البحـــث

فى مجال علم النفس عامة وعلم النفس الرياضي خاصة فالخصائص البدنية الفريدة و المواهب التي يتميز بها الرياضيون تدعوا إلي العديد من المتخصصين فى علم النفس الرياضــي إلـي

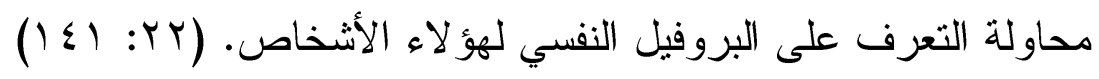
كما يعتبر توجه المنافسه من المفاهم الحديثه فى المجال الرياضي فيري محمود عنان (990 (م) ان موضوع الاتجاهات نحو المنافس حتى السنوات الاخيه لم تكن موضوعا للبحث 


\section{๑. $\varepsilon$}

و الدراسه بالرغم من الافتر اض القائم بان الاتجاهات للاعب نحو المنافسه فى اللقاءات انمـــا تؤثر بدرجه ما على الطريقه التى سيلعب بها ويضيف ان الاتجاهات نحو المنافس جانب هام من جو انب الاعداد النفسى. (1) (109) وتعتير السمات الانفعاليه من الخصاص النفسيه الهامه باعتبار انها تعبر عـن شـــهـ الانفعال وتستخدم بشكل متبادل مع كل من مصطلحى التشيط وتعبئه الطاقه وهى عاده نتــاج العديد من الانفعالات الهامه و التى تؤثز على الاداء الرياضى. (Y (Y: Y I)

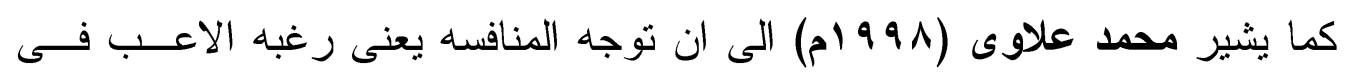

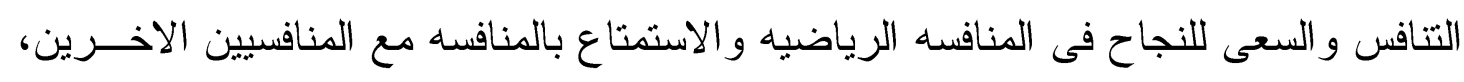
و ان الاعب الذى يفتقر الى السمات النفسيه الاجابيه لن يستطيع مهما بلغت قدر اته ومستوياته

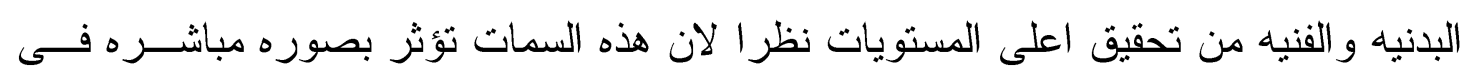

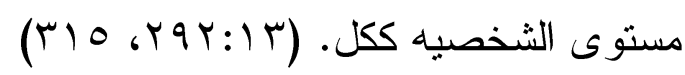

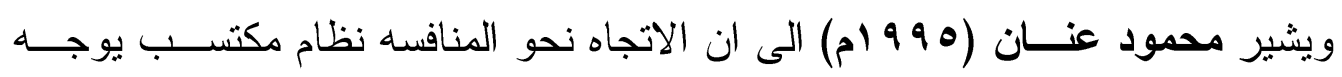
بطريقه العاده الشعوريه بدرجه من درجات سلوك الاعبين قبل المبار اه واثنائها ايضا، وتحكمه

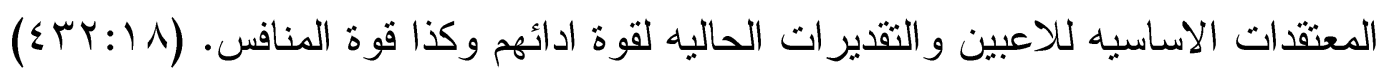
ويشير مارتنز 99V) martens (1م) ان السمات النفسيه للاعب تتاثز بدافعيه الانجاز

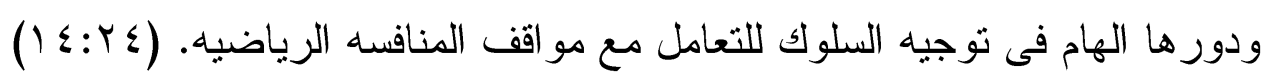

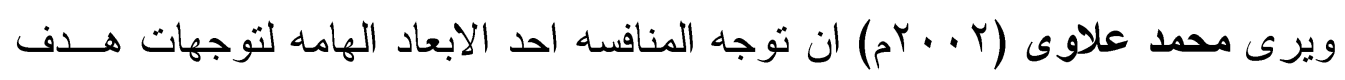

$$
\text { الانجاز الرياضى. (10: (1) }
$$

و الكار اتيه تعتبر من الرياضات الفردية التي يعتمد نجاح أي لاعب أو فريقه على مدى

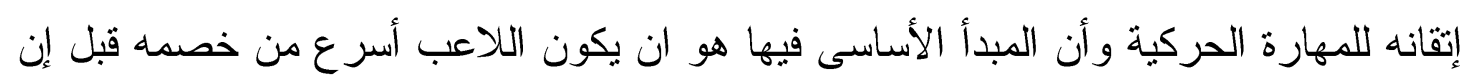
يكون اقوي منة وان هدف التدريب هو تطوير أساسيات الكار اتيه وبعض من الصفات البدنية

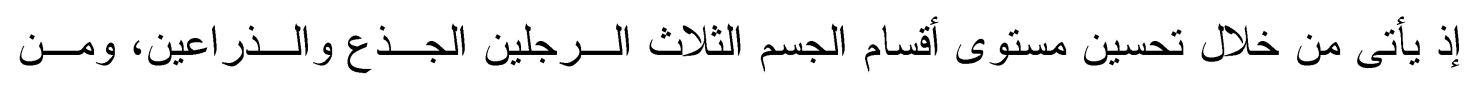

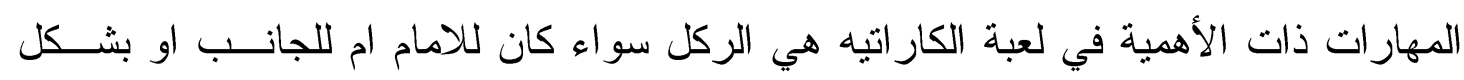

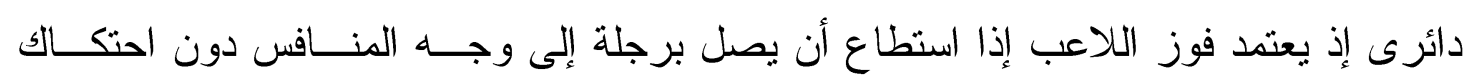

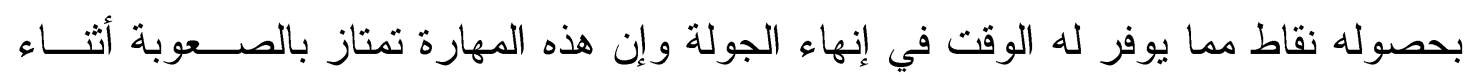
أدائها ولهذا يجب إعطائها فتز ات زمنية كافية للتدريب وتوسيع مداها.

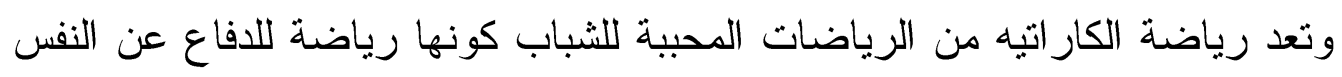
بأساليبها المختلفة وتعدد أقسامها كالكوميتية (القتال الفعلي ضمن قانون اللعبة) و الكاتا (القتــال 


\section{$\bullet \cdot \bullet$}

الوهمي) وتتوع طرق و أساليب التدريب عليها، كما أنها تتتاسب مع جميع المر احل العمريـــة

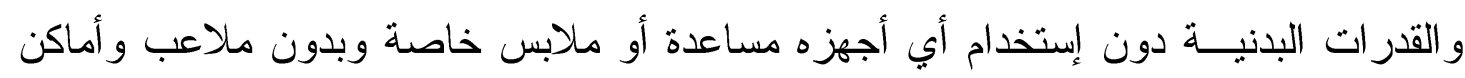

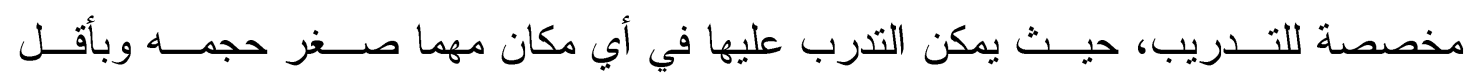

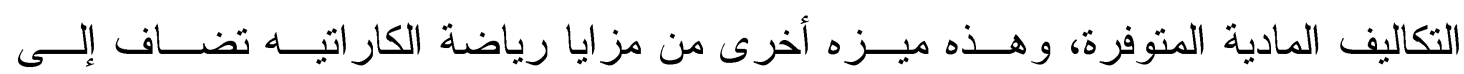
ممارسيها ومحبيها.

كما أنه تعددت الدراسات لوصف وتحليل الظو اهر النفسية المختلفة وذلك للوقوف على التى

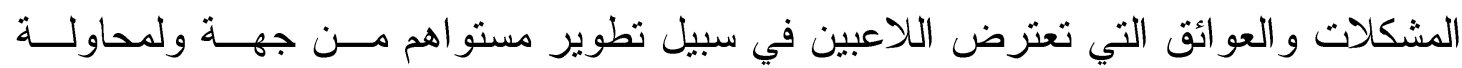

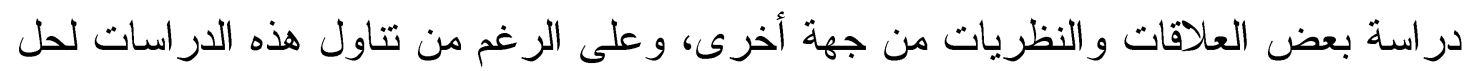

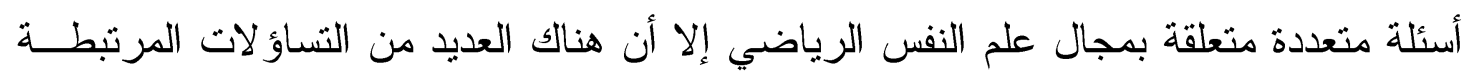

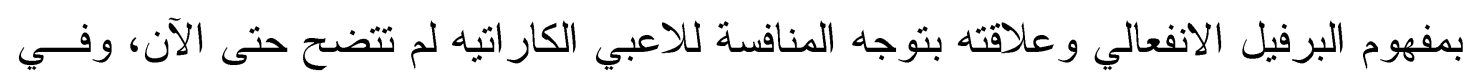

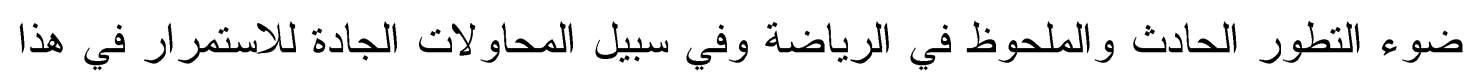

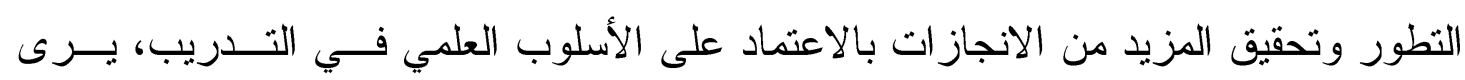

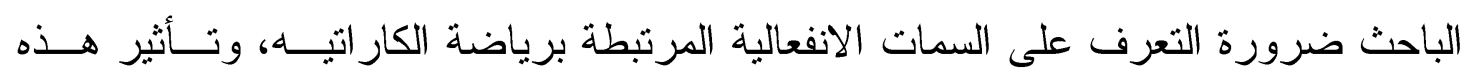

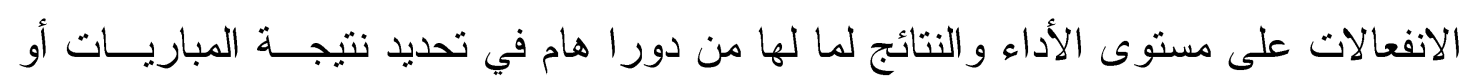
استمر ارية اللاعب فى التدريب أو العزوف عنده.

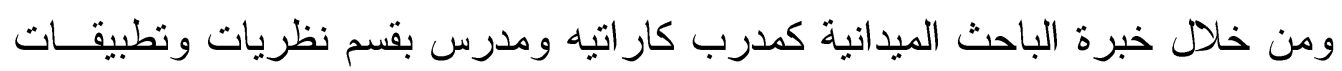

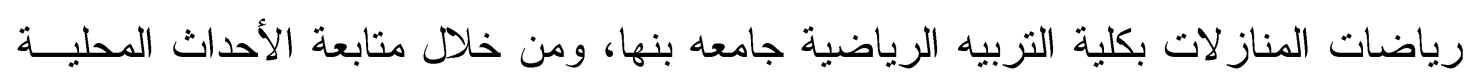

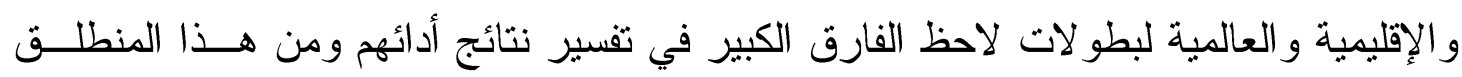

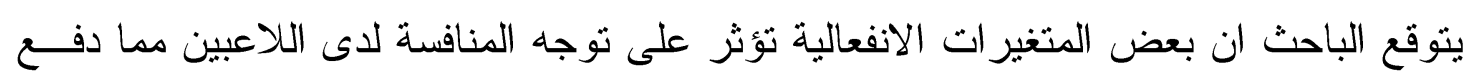
الباحث لإجر اء هذا البحث. البحث. هل البحث:

يهدف البحث إلى "دراسة البروفيل الاففعالي وعلاقته بالتوجه التنافسى لدى لاعبـي الكار اتيه" من خلال: 1- التعرف علي البروفيل الانفعالي للاعبي الكار اتيه. r- التعرف على العلاقة بين البروفيل الانفعالي و التوجه التنافسى لاعبي لاعبي الكار اتيه.

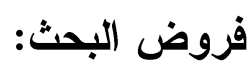
1- توجد فروق دالة إحصائيا فى البروفيل الانفعالي و التوجه التتافسى بين لاعبي الكار اتيـــ وفقاً للجنس. 
- 7

ب- توجد فروق دالة إحصائيا فى البروفيل الانفعالي و التوجه التتافسى بين لاعبي الكار اتيـهـ

$$
\text { وفقا لنوع الأداء (كاتا، كومتيه). }
$$

ب- توجد علاقة ارتباطيه دالة إحصائيا بين البروفيل الانفعالي و التوجـهـ التنافسـى لاعبــي

$$
\text { تعريفات البحث: }
$$

- البروفيل الانفعالي: Emotional Profile (")

مجموعة من السمات الانفعالية النى تعبر عن شدة الانفعال وهى المسئولة عن سلوك

$$
\text { اللاعب في التدريب و المنافسة. }
$$

\section{- توجه المنافسة: Competitiveness Orientation.}

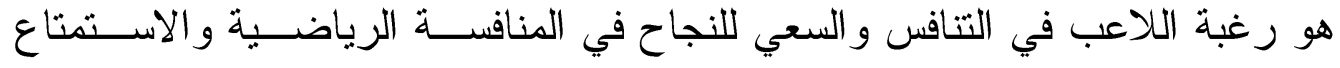

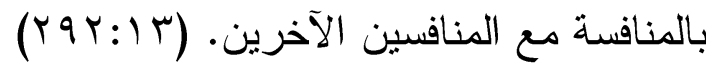

$$
\begin{aligned}
& \text { الاراسات المرجعية: }
\end{aligned}
$$

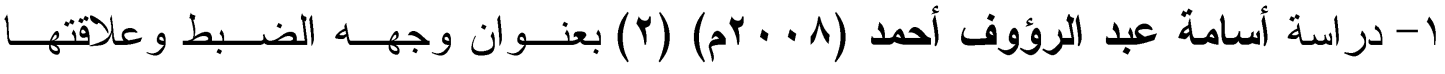

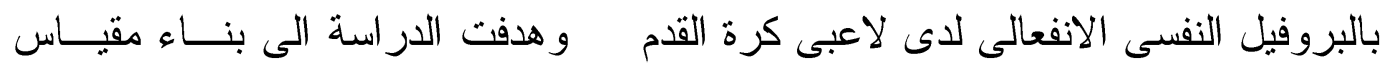

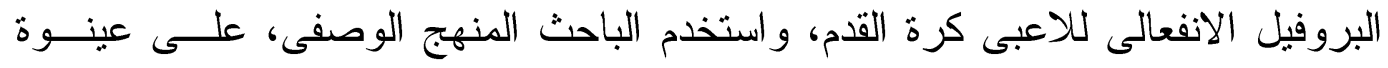

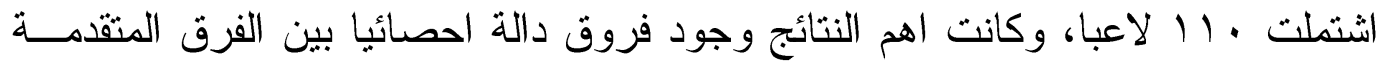

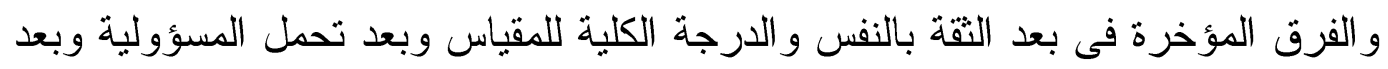

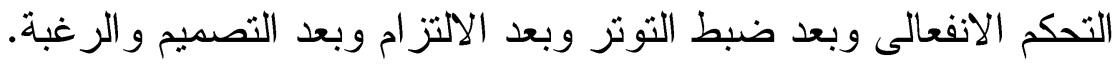

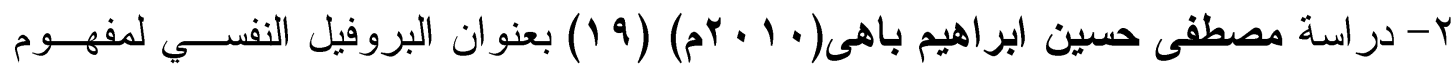

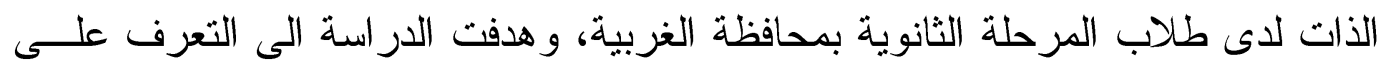

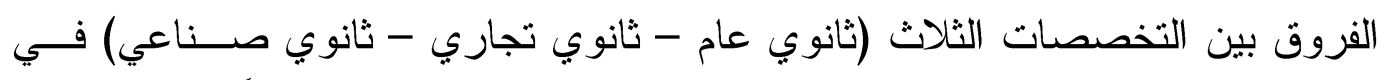

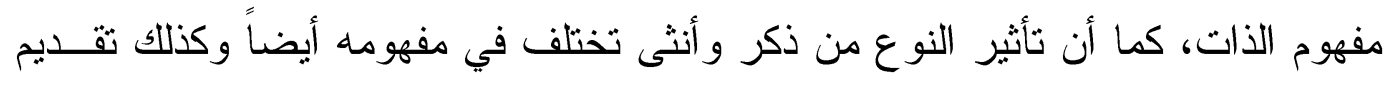

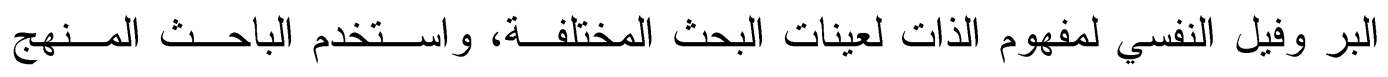

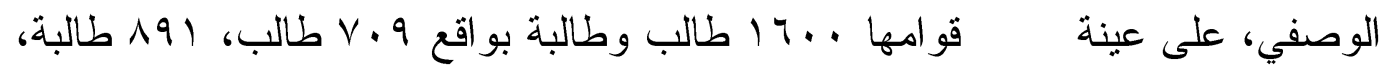

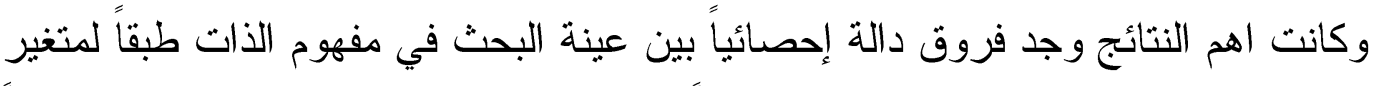

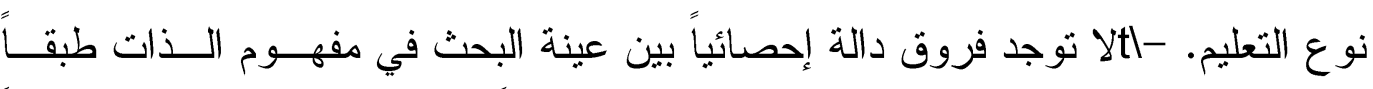

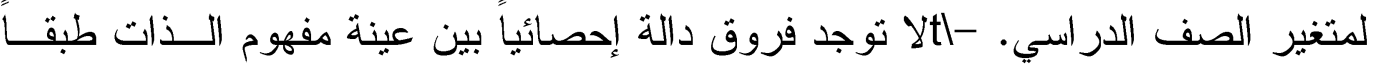

" تعريف إجرائي 


\section{$0 . v$}

لمتغير النوع. -التوجد علاقة ارتباطية دالة إحصائياً بين مفهوم الذات العــام ومفــاهيم الذات المختلفة لدى عينة البحث. - -أثقيم نموذج للبر وفيل النفسي لمفهوم الذات.

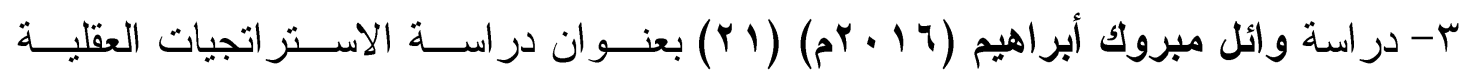
و البروفيل التتافسي لملاكمي الشباب و علاقتهم بمستوى فاعلية الأداء المهاري: در اســـة

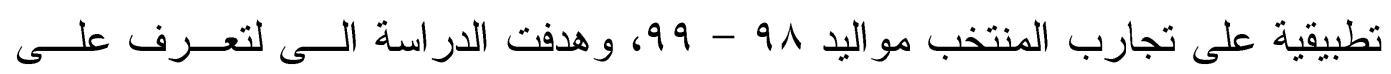
الاستر اتيجيات العقلية و البروفيل التتافسي لملاكمي الشباب و علاقتهم بمســتوى فاعليـة الأداء المهارى و هذا سوف يساهم في التعرف على بعض الجوانب النفســية و التتافسـية التي في حال الاهتمام بها سوف تساعد في الوصول للمستوي متقدم بمســتوى فاعليــة الأداء المهارى أثناء المنافسات الرياضية، واستخدم الباحث المنهج الوصفى، على عينــة

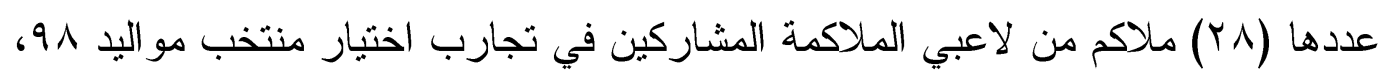
، وكانت اهم النتائج وجود فروق ذات دلالة إحصائية بين الملاكمين الفائزين

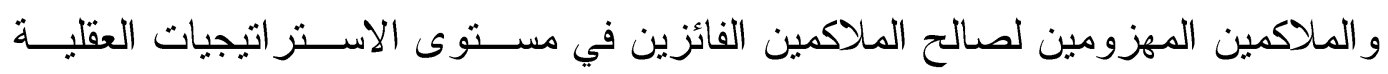
بأبعادها المختلفة، وجود فروق ذات دلالة إحصائية بين الملاكمين الفائزين و الملاكمـين فين

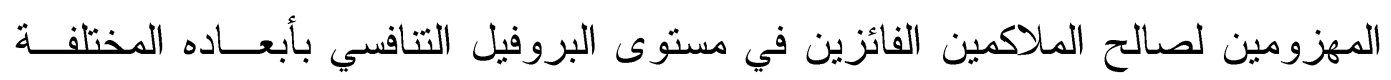

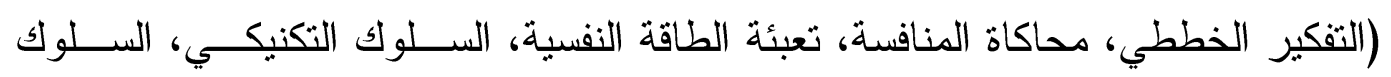
التكتيكي، الاتزان الانفعالي) عدم وجود فروق ذات دلالة إحصائية في الأبعــاد الآتيــة

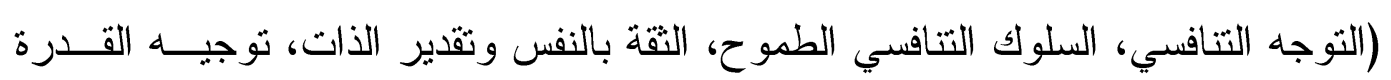

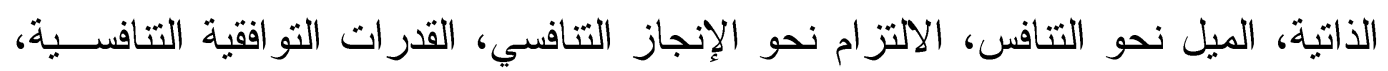
السلوك الاجتماعي التوافقي، ضبط القلق التتافسي، مواجهة المواقف المتغيرة، الســلوك الإيجابي للمهمة، استقلالية الدافع الذاتي) وجود ارتباط دال إحصائيا بين جميــع أبعـاد مقياس الاستر اتيجيات العقلية بأبعادها المختلفة ومستوى فاعلية الأداء المهــارى وجــــود ارتباط دال إحصائيا بين معظم أبعاد مقياس البروفيل التنافسي ومســتوى فاعليــة الأداء المهارى ما عدا محور متطلبات النشاط التتافسي، القدرة على اتخاذ القرار .

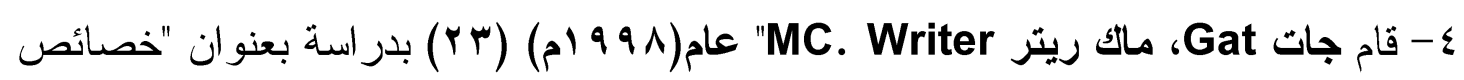
الشخصية لدى لاعبي الدراجات المتتافين و الترويحيين" وذلك بهدف مقارنة الخصائص

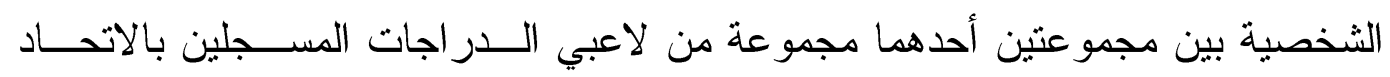

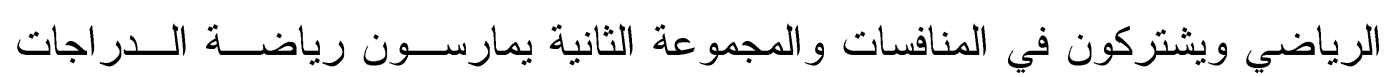

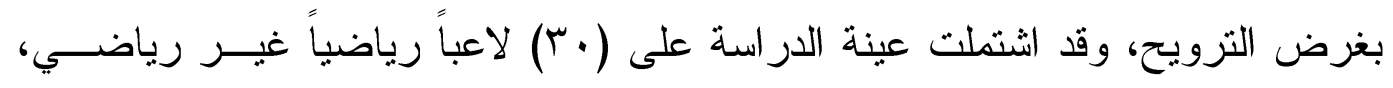

\section{مجلة أسيوط لعلوم وفنوز التربية الرياضية}




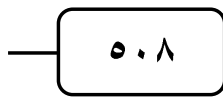

و واستخام اختبار العو امل الستة عشر "كاتلل" كاداه في جمع البيانات، وقد توصلت نتـائج

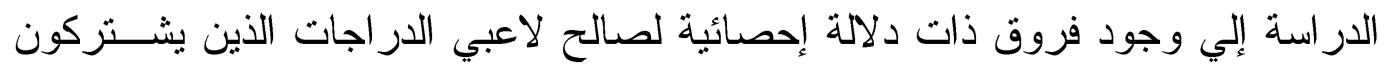

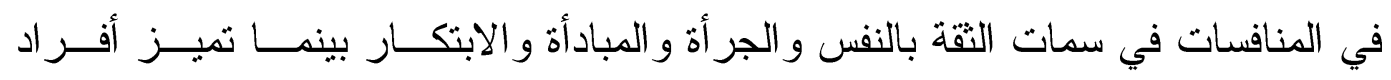

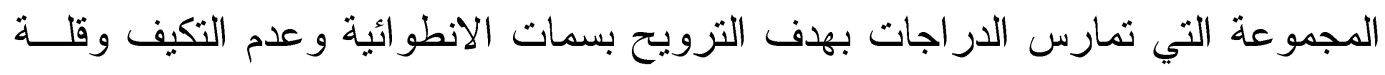
الخبرة في المواقف الاجتماعية المختلفة.

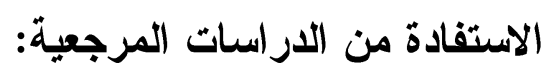

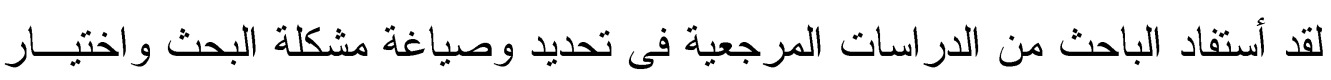

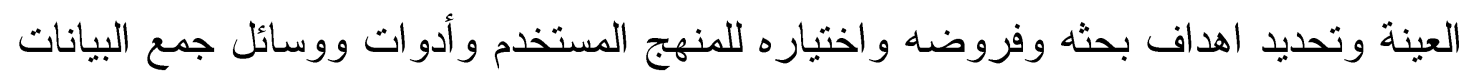

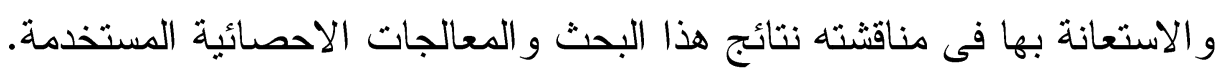

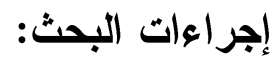

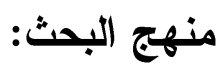
استخدم الباحث المنهج الوصفي بإتباع الأسلوب السحي وذلك لملائمنه لأهداف البحث

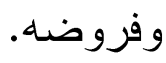

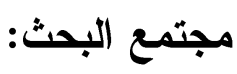
يتمتل مجتمع البحث من لاعبي الكار اتيه بالدرجة الاولى و المسجلين بالاتحاد المصري

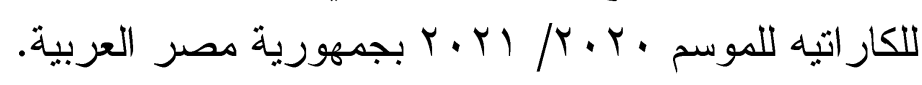

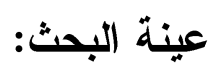

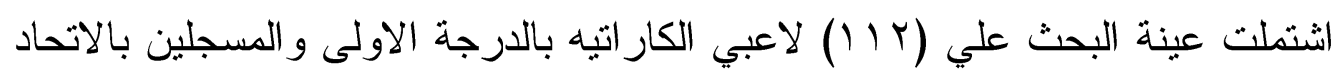

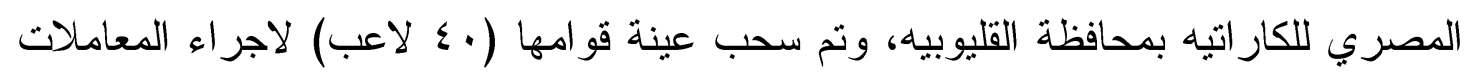

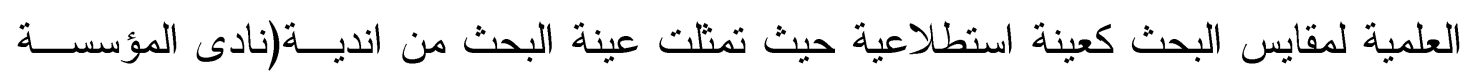

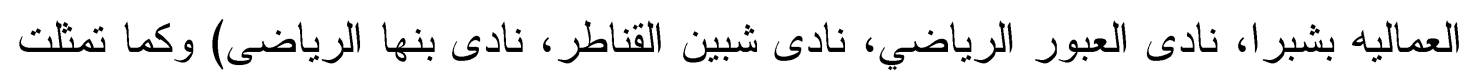

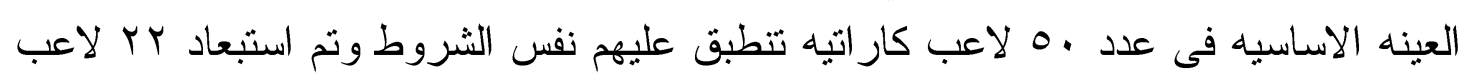

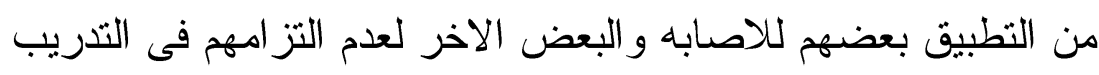

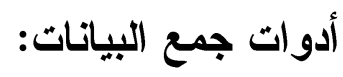

- مقياس البروفيل الانفعالي للاعبى الكار اتيه: "إعداد الباحثث"

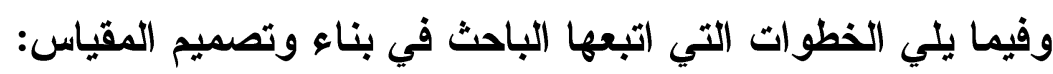

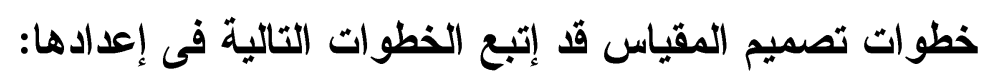

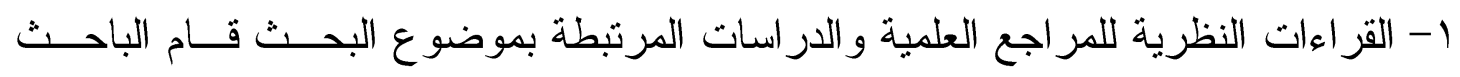

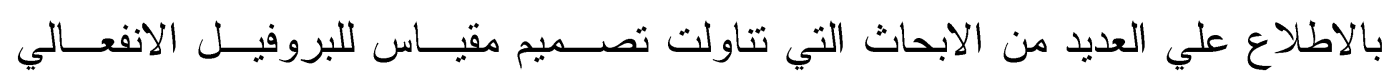




\section{9}

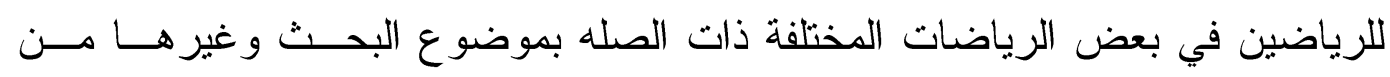

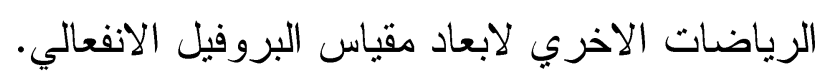

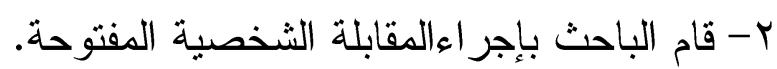

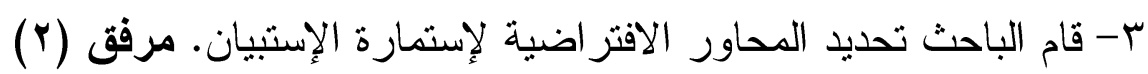

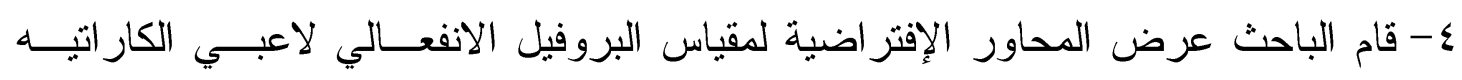

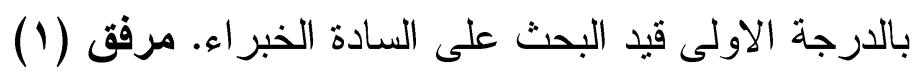

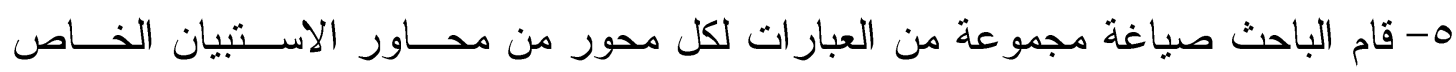

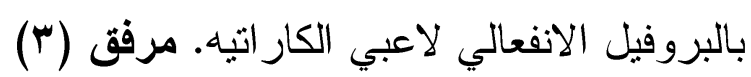

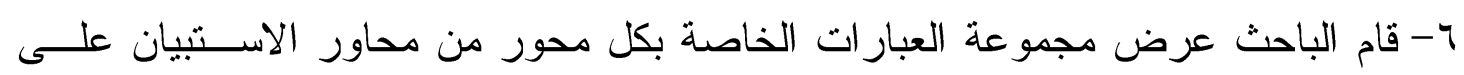
السادة الخبر اء.

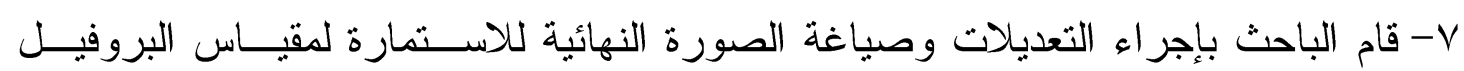

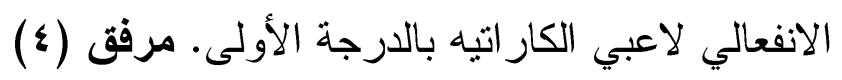
شروط الخبير: • أن يكون استاذ فى مجال علم النفس الرياضي.

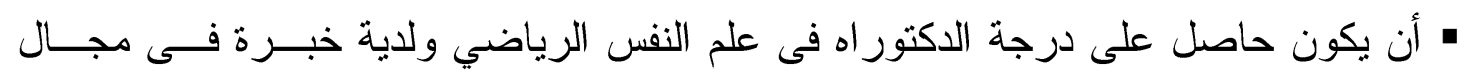

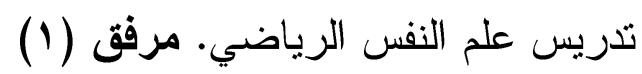
المعاملات العلمية للاستمارة: صدق المحتوى:

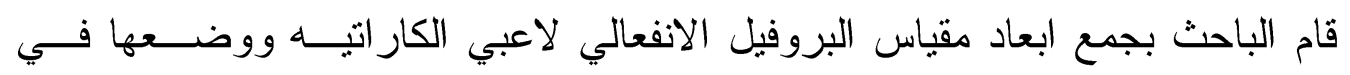

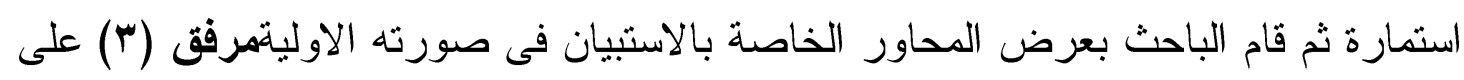

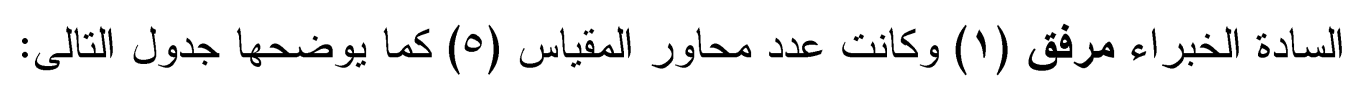

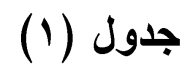
آراء الخبراء حول محاور الاستبيان ن=ه (1)

\begin{tabular}{|c|c|c|c|}
\hline النسبة المئوية & التكرار & المجـــــــــــور & م \\
\hline$\% 1 \ldots$ & 0 & التحكم الآفعالى & 1 \\
\hline$\% 1 \ldots$ & 0 & تحمل المسؤولية & $r$ \\
\hline$\% \wedge$ & $\varepsilon$ & الثقة بالنفس & $r$ \\
\hline$\% 1 \ldots$ & 0 & عدم التردد & $\varepsilon$ \\
\hline$\%$ \%. & $\varepsilon$ & الرغبــة و التصميم & $\circ$ \\
\hline
\end{tabular}




\section{1 .}

يوضح الجدول السابق تكرار الموافقة والنسب المئوية حول استطلاعية أر اء الســادة

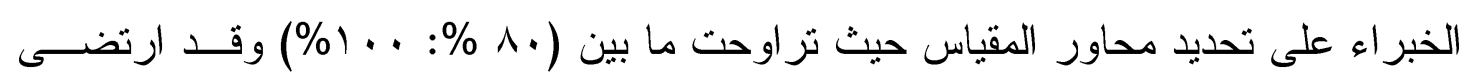
الباحث وما و افق عليه الساده الخبر اء بنسبة أعلى من • V \% للمحاور التـى ســيتم قبولهـــا، ليصبح المقياس عدد المحاور التي تم الموافقة عليها (0) محاور لمقياس البروفيل الانفحسالي لاعبي الكار اتيه.

وقد قام الباحث بصياغة مجموعة من العبارات لكل محور مــن محســاور المقيــاس

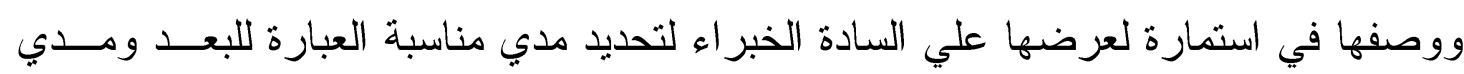
مناسبة الصياغة، و عرض ميزان التقدير علي السادة الخبراء حيث كانت عدد العبارات فــي

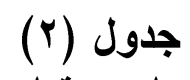
الصورة الاولية (· (7) عبارة.

آراء السادة الخبراء حول عبار ات محاور مقياس البروفيل الاتفعالي لاعبي الكار اتيه

\begin{tabular}{|c|c|c|c|c|c|}
\hline الر غبـــــة والتصميم & عدم التر دد & الثقة بالنفسر & تحمل المسؤوولية & التحكم الانفهالى & م م \\
\hline$\% \wedge$. & $\% 1 \ldots$ & $\% \wedge$. & $\% 1 \ldots$ & $\% \wedge$. & 1 \\
\hline$\% 1 \ldots$ & $\% \wedge$ & $\% 1 \ldots$ & $\% 1 \ldots$ & $\% 1 \ldots$ & $r$ \\
\hline$\% \wedge$ & $\% 1 \ldots$ & $\% 1 \ldots$ & $\% 1 \ldots$ & $\% 1 \ldots$ & r \\
\hline$\% \wedge$. & $\% \wedge$. & $\% \wedge$. & $\% \wedge$. & $\% 1 \ldots$ & $\varepsilon$ \\
\hline$\% 1 \ldots$ & $\% 1 \ldots$ & $\% \wedge$. & $\% 1 \ldots$ & $\% 1 \ldots$ & 0 \\
\hline$\% 1 \ldots$ & $\% \wedge$ & $\% \wedge$. & $\% 1 \ldots$ & $\% \wedge$ & 7 \\
\hline$\% 1 \ldots$ & $\% \wedge$. & $\% 1 \ldots$ & $\% 1 \ldots$ & $\% \wedge$. & V \\
\hline$\% 1 \ldots$ & - & $\% 1 \ldots$ & $\% 1 \ldots$ & $\% 1 \ldots$ & $\Lambda$ \\
\hline$\% 1 \ldots$ & - & $\% 1 \ldots$ & $\% 1 \ldots$ & $\% 1 \ldots$ & 9 \\
\hline$\% \wedge$. & - & $\% \wedge$. & $\% \wedge$. & $\% 1 \ldots$ & 1. \\
\hline$\% 1 \ldots$ & - & - & - & - & 11 \\
\hline$\% \wedge$. & - & - & - & - & Ir \\
\hline
\end{tabular}

يوضح الجدول السابق تكر ار الموافقة والنسب المئوية حول أراء السادة الخبر اء على الى

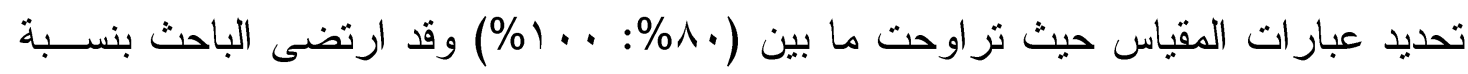
أعلى من · ^ \% للعبار ات و اصبح عدد العبار ات (9 ).

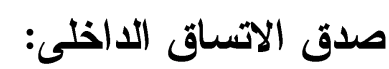

قام الباحث بتطبيق المقياس على عينة قو امها ( • ع) افراد من مجتمع البحــث ومــن

خارج عينة البحث الاساسية لها نفس مواصفات تم حساب معاملات الارتباط لبيرسون بين: ا- كل عبارة من عبار ات المقياس ودرجة المحور التى تتنمى اليه. r- ب الابعاد و الدرجة الكلية للمقياس. 


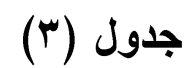

معامل ارتباط عبارات المحور الأول التحكم الانفعالى (ن = . ع )

\begin{tabular}{|c|c|c|}
\hline معامل الارتباط & العبــارات & مـ \\
\hline$* . .7$. & اخشي من مو اجهه المنافس الذي سبق وهزمني & 1 \\
\hline$* . .74$ & اسيطر على انفعالاتى فى المو اقف الحرجه. & $r$ \\
\hline$* .0 \mathrm{Or}$ & اري بأننى لا استطيع التحكم في انفعلاتي. & r \\
\hline$* . . V \mu$ & اشعر بالتوتز عندما يكون الهنافس قوى & $\varepsilon$ \\
\hline$* . .7 V \leqslant$ & اثعر بالضيق عندما يكون ادائى ضعيف. & 0 \\
\hline$* . . V 4 \lambda$ & اشجع زملائي على التحكم في انفسهر الثناء المبار اه & 7 \\
\hline$* . . \vee \wedge 0$ & استطيع اللعب بسهوله في اصعب اوقات المباراه & $\mathrm{v}$ \\
\hline$* .071$ & استطيع الاحتفاظ بهاوئى عند اتخاذ الحكم قرار خاطئ. & $\Lambda$ \\
\hline$* . . V \backslash \varepsilon$ & أقو م بإصدار رد فعل عنيف ومتونر في المو اقف الحرجه. & 9 \\
\hline$* . . \$ 99$ & اهنيء المنافس في حالة فوزه بالمبار اه. & 1. \\
\hline
\end{tabular}

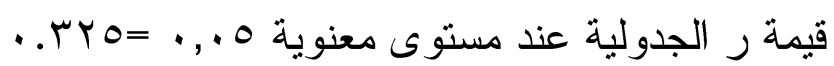

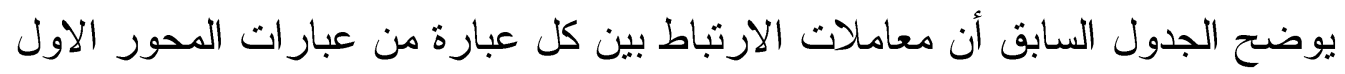

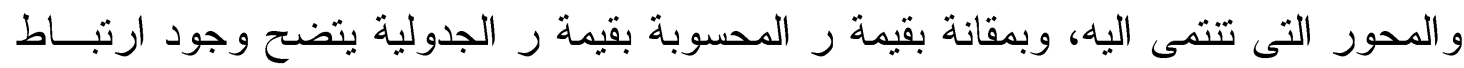
دال احصائياً مما يؤكد على صدق الاتساق الداخلى لعبار ات المحور الاول.

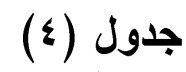

معامل ارتباط عبارات المحور الثاني تحمل المسؤولية (ن= . ع)

\begin{tabular}{|c|c|c|}
\hline معامل الارتباط & العبــارات & م \\
\hline$* .0 \mathrm{VI}$ & اقوم بالتندريب لفتر ات طويله لاحافظ على مستو ايه. & 1 \\
\hline$-* . .911$ & اعتذر عندما اخطى فى المنافسة. & r \\
\hline$* . T \Lambda \mathrm{r}$ & ابذل اقصى جهاى كى اكون قدوه حسنه في التنريب. & r \\
\hline *.VKI & ابذل جهدا اضافيا في التنريب. & $\varepsilon$ \\
\hline *. .V\ะ & افضل المدرب الذى لا يسند الى مهمات صعبه. & 0 \\
\hline$* .010$ & احاول اظهار قدرتى الفرديه في المنافسه. & 7 \\
\hline$* . .790$ & قو بالاعمال التى تسند الى في التندريب و المنافسه & $\mathrm{V}$ \\
\hline *.VOT & اثشعر بعدم قدرتى على القيام بالجه المطلوب اثناء المنافسة. & $\Lambda$ \\
\hline$* . . V 7 \mathrm{~V}$ & عدم اهتمامى بالخطاء الذى ارتكبته اثناء المنافسة. & 9 \\
\hline$* . . \leqslant 94$ & افضل تنفيذ الو اجبات الصعبده. & 1. \\
\hline
\end{tabular}

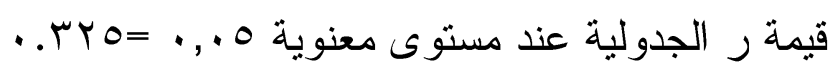

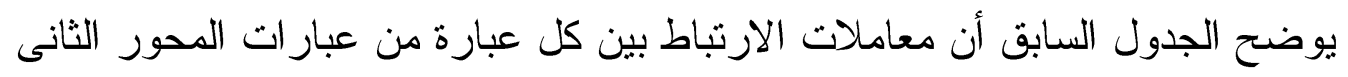

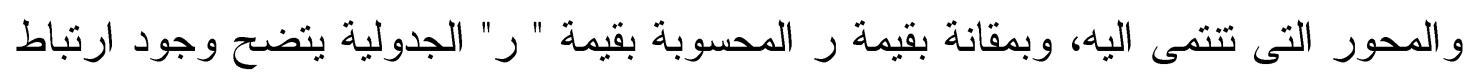

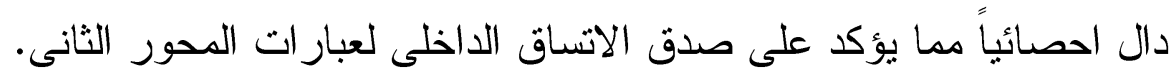


جدول (0)

معامل ارتباط عبارات المحور الثالث الثقة بالنفس (ن= • ـ؛)

\begin{tabular}{|c|c|c|}
\hline معامل الارتباط & العبـــارات & مـ \\
\hline$* . .0 \mathrm{Vr}$ & استطيع هزيمة اي لاعب منافس. & 1 \\
\hline$* .0 \cdot 1$ & اثق في نفسى اثناء المنافسة. & r \\
\hline$* .07 \mathrm{~V}$ & اؤمن بقدر اتى البدنيه. & $r$ \\
\hline$* .7 / Y$ & أرى عدم قدرتى على تنفيذ ما يطلبه المدرب. & $\varepsilon$ \\
\hline$* . \leqslant \vee q$ & اتوقع الفوز قبل ان تبدا الدنافسة. & 0 \\
\hline$* .7 \mu \mu$ & اشعزر بعدم تقتى في قدر اتى البدنيه. & 7 \\
\hline *.V7 & اشعر بالتوتز في المو اقف المناخيه فى المبار اه. & $\mathrm{V}$ \\
\hline$\% . .0 Y \Lambda$ & ينتابنى الخوف عندما أثنعر أن المنافس أُقوي منى & $\Lambda$ \\
\hline$* \cdot .7) \varepsilon$ & استظيع اتخاذ القرارات السريعه اثناء المنافسة. & 9 \\
\hline$* .007$ & اثق في قدرتي على الاداء في المنافسة. & 1. \\
\hline
\end{tabular}

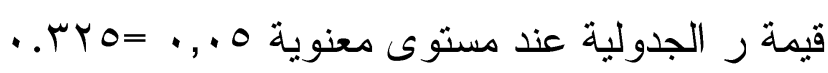

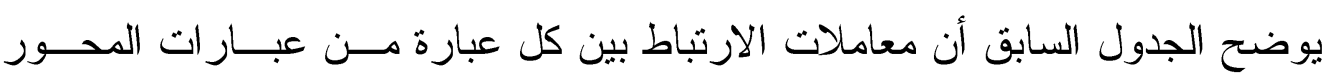

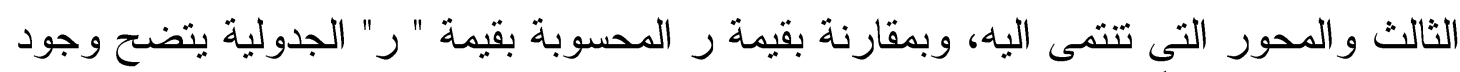

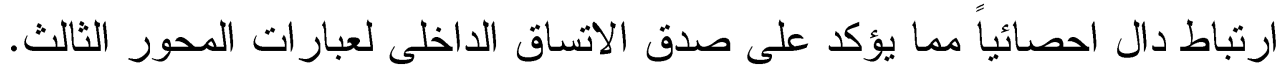

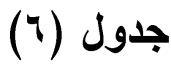

معامل ارتباط عبارات المحور الرابع عدم التردد (ن= + ع )

\begin{tabular}{|c|c|c|}
\hline 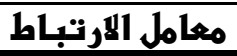 & العبـــارات & م \\
\hline$* . .0 \mathrm{Vr}$ & دائما ما أقوم بأداء الحركات في الوقت المناسب & \\
\hline$* .071$ & لدى القدرة على توقع اداء المنافس فى الوقت ألمناسب & $r$ \\
\hline$* .100$ & آقو ب باداء حركات اللعب دون الاهتمام برد فعل المنافس & r \\
\hline$* .011$ & يسبقنى المنافس بالهجو المضاد نتيجة لتزرددى & $\varepsilon$ \\
\hline$* . .7 \leqslant \varepsilon$ & الهجوم السريع أسلوبي لـفاجأة الدنافس & \\
\hline$* . \vee \vee \wedge 0$ & ينتابني الثز دد أثناء الثنافسات الهامة & 7 \\
\hline$* . . \leqslant \leqslant \Lambda$ & أسبطر دائما و اتحكم في اللعب منذ بدء المنافسة & $\mathrm{V}$ \\
\hline
\end{tabular}

قيمة ر الجدولية عند مستوى معنوية 0 ., ل.

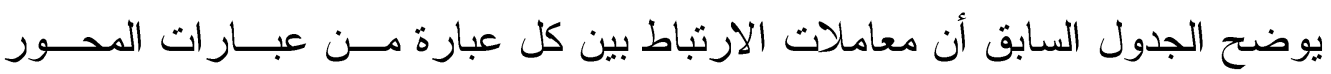

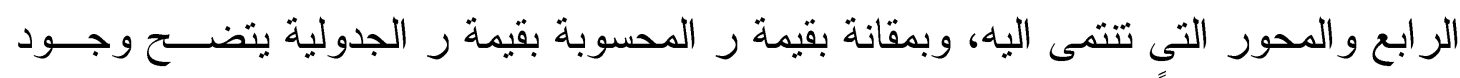

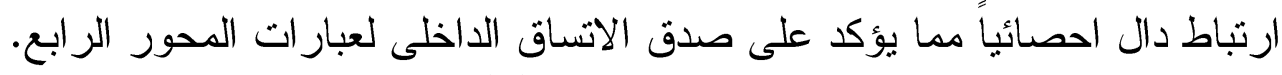

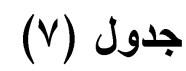

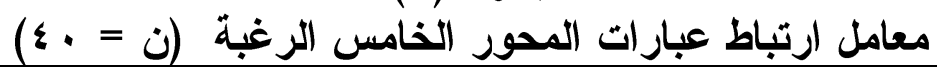

\begin{tabular}{|c|c|c|}
\hline معامل الار تباط & العبــارات & مـ \\
\hline$* .007$ & أخشى من الهزيمة امام الجمهور & 1 \\
\hline *..V ${ }^{\mu} \mathrm{V}$ & استمر في المنافسة بجد رغم انخفاض مستوى المنافس المنافسة & $r$ \\
\hline *.VI乏 & أنسحب من المنافسة عند أدائى بصورة ضعيفة & $\mu$ \\
\hline$* .0 \mathrm{HV}$ & احاول دائما أن أصل إلى أفضل مستوى لى & $\varepsilon$ \\
\hline$* .7119$ & آكثف تدريباتى من أجل تعويض الهزيمة & 0 \\
\hline$* .09 \mathrm{~V}$ & لا بسعدنى أن أتدرب بمفردي & 7 \\
\hline التربية الرياضية & مجالة أسيوط لعلوم وف ل & \\
\hline
\end{tabular}




\section{تابع جدول (v)}

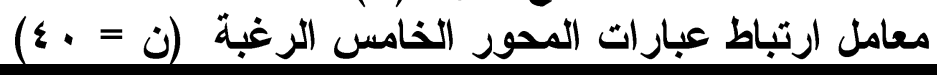

\begin{tabular}{|c|c|c|}
\hline معامل الار تبـاط & العبـــارات & م \\
\hline$* .0 \leqslant 1$ & أشتعر بالسعادة لمجرد اللعب رغم وجود عدد كبير من الأخطاء & V \\
\hline$* . \vee \wedge \circ$ & استمر في الانتظام على التذريب لفترة طويلة & ᄉ \\
\hline$* .9 Y$. & لا أهتم بتعليمات المدرب عندما أكون مندمجا في اللعب & 9 \\
\hline$* . \leqslant 77$ & استمتع بالتحدى في المنافسات الصعبة & 1 . \\
\hline.$\Sigma T Y$ & اتحمس كثثر ا في التندريب و المنافسه. & 11 \\
\hline$\therefore V \leqslant 0$ & احب وجود حاله التحدى في المبار اه. & Ir \\
\hline
\end{tabular}

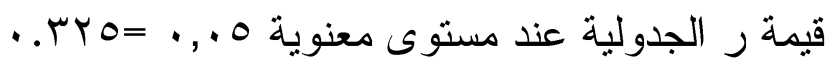

يوضـح الجدول السابق أن معاملات الارتباط بين كل عبارة مــن عبــار ات المحسـور

الخامس و المحور التىى تتنمى اليه، وبمقانة بقيمة ر المحسوبة بقيمة ر الجدولية يتضح وجــود

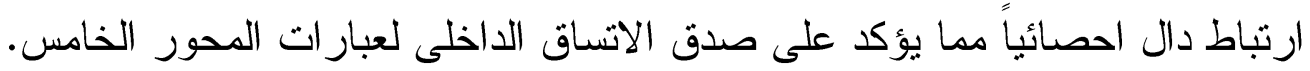
جدول (^)

معامل الارتباط بين المحاور والارجة الكلية للمقياس ند) ، ع

\begin{tabular}{|c|c|c|}
\hline الارتباط & المح & م \\
\hline$* . . \vee \leq \Lambda$ & التحكم الانفعالي & 1 \\
\hline$* .011$ & تحمل المسؤولية & $r$ \\
\hline$* .7 \leq$. & التقة بالنفس & r \\
\hline$* . \wedge \leq 1$ & عدم التردد & $\varepsilon$ \\
\hline$* . \vee \wedge 9$ & الر غبة و التصميم & 0 \\
\hline
\end{tabular}

قيمة ر الجدولية عند مستوى معنوية 0 ., . =

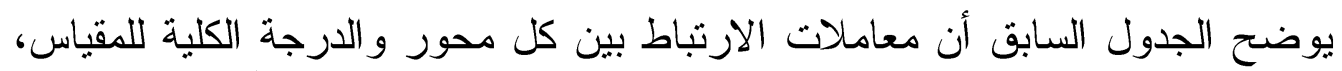

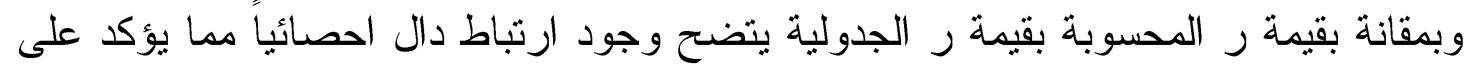
صدق الاتساق الداخلى لمحاور المقياس. ثبات المقياس:

وقد استخدم الباحث لحساب معامل الثبات الاستبيان معامل الفا كورنباخ:

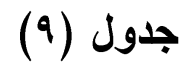

قيم الفا كرونباخ لحساب ثبات الاستبيان ن= ـ ع

\begin{tabular}{|c|c|c|}
\hline 1لارتباط & المحــاور & م \\
\hline$* . V \backslash \leq$ & التحكم الانفعالى & 1 \\
\hline$* . \wedge \leqslant 0$ & تحمل المسؤولية & $r$ \\
\hline$* .91 \leq$ & الثقة بالنفس & r \\
\hline$* .7 V \leqslant$ & عدم التزدد & $\varepsilon$ \\
\hline$* . \vee \wedge$. & الر غبة و التصميح & 0 \\
\hline
\end{tabular}

قيمة ر الجدولية عند مستوى معنوية ه ., =. = مجلة أسيوط لعلوم وفنـوز التربية الرياضية 


\section{$01 \varepsilon$}

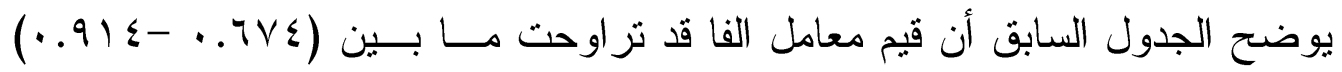
و هى قيم مرضية لقبول ثبات الاستبيان؛ حيث قام الباحث بادماج عبارة المقياس ليصبح فـي صورته النهائية مرفق (ع) وبميز ان تقدير خماسى التدريج (دائما، غالباً، أحياناً، نادراً، أبداً). ثانياً: التوجه التنافسى:

قام محمد حسن علاوى (9 991 ( ) بتصميم قائمة التوجه التتافسى لقياس توجه اللاعب

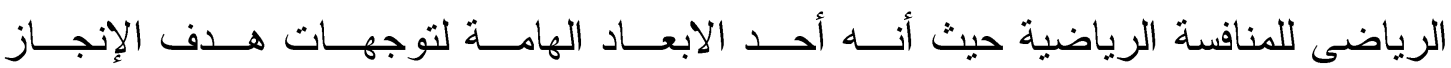

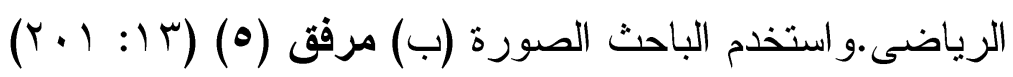
وصف القائمة:

تتكون من · r عبارة نصفها إيجابى فى إتجاه التوجه التتافسى و النصف الأخر ســلبى فى عكس التوجه التتافسى، ويقوم اللاعب بالإجابة على عبار ات القائمة على مقياس خماسـى

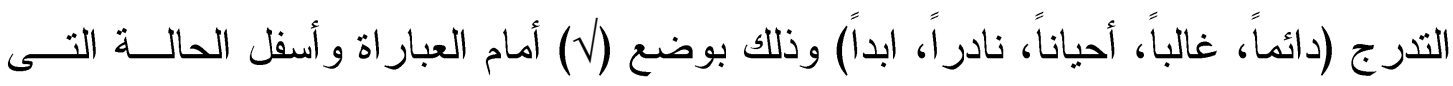

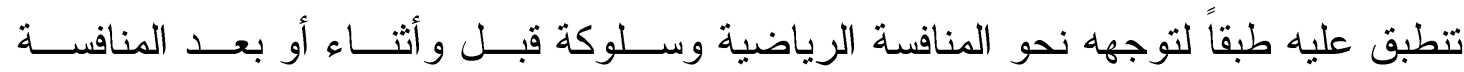
الرياضية.

مفتاح الصحيح: للقائمة درجة كلية تعبر عن التوجه التتافسى للاعب و لا يوجد للقائمة محاور، تتكــون

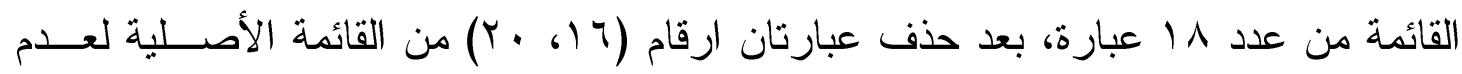

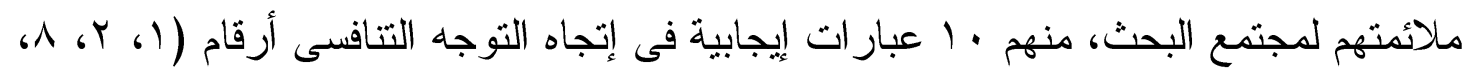

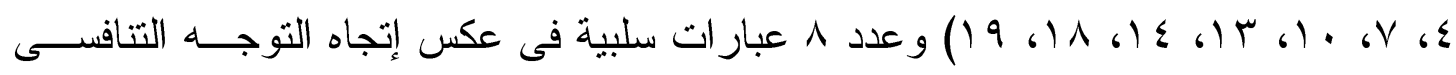

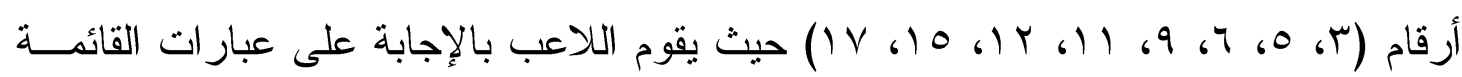
على مقياس خماسى التدريج (دائماً، غالباً، أحياناً، نادراً، أبداً).

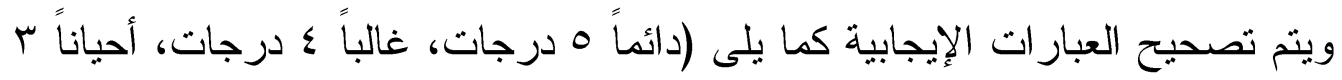

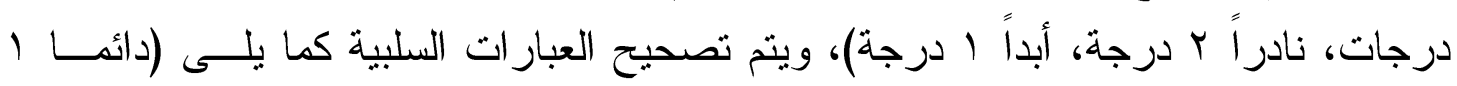

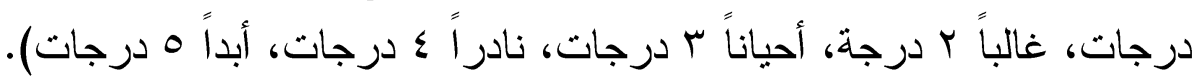
وتثرواح الدرجات ما بين (1 1: . 9). وتفسر الدرجات كالتالى: - الدرجات من ( • r: r؟): تعبر عن توجه اللاعب للمنافسة بدرجة منخفضة.

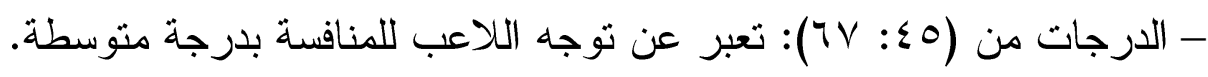
- الدرجات من (1) ؟ج: . . 1): تعبر عن توجه اللاعب للمنافسة بدرجة عالية. 


\section{المعاملات العلمية للقائمة فى البحث الحالى:}

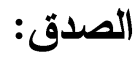

لحساب صدق القائمة استخدم الباحث صدق الاتساق الداخلي حيث تم تطبيق القائمسـة

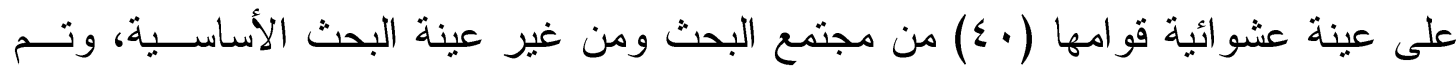

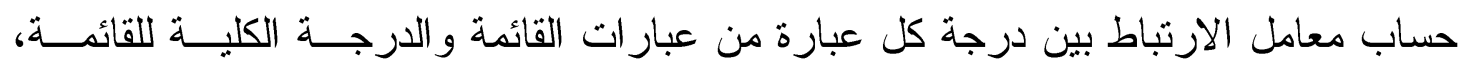

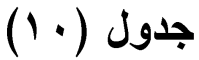

$$
\text { و الجدول التالي يوضح النتيجة. }
$$

معاملات ارتباط عبارات قائمة التوجه التنافسي بمجموع درجات القائمة (ن= • ع)

\begin{tabular}{|c|c|c|}
\hline ) & المهـــــــاور & م \\
\hline$* .791$ & أدائى في الدبار اة يكون أفضل من أدائى فى التدريب. & \\
\hline$* . . \sum V \uparrow$ & أستطيع التزكيز بسر عة بعد قيامى لبعض الأخطاء في المبار اة. & r \\
\hline$* . .7 \%$ & أرتكب بأخطاء كثيرة في المبار اة الحساسة و الهامة. & r \\
\hline$* .0 \%$. & أقو بأفضل أداء في المباريات الصعبة بدرجة أكبر من المباريات السهلة & $\varepsilon$ \\
\hline$* . . V 11$ & أثنتعر بالذوف عندما يتفوق المنافس أثناء سير المبار اة. & o \\
\hline$* .7 T \mathrm{r}$ & لا أتذكر ما حدث في المبار اة بعد نهايتها. & 7 \\
\hline$* .0 Y \mathrm{~T}$ & أنثترك في البطولة وكل تفكيري هو أن أتنفوق فيها. & $\mathrm{v}$ \\
\hline$* . . T \cdot Y$ & يكون أدائي أفضل في المبار اة التي يشاهدها أعداد كبيرة من المشاهدين. & $\Lambda$ \\
\hline$* . .71 \mathrm{r}$ & أثنتعر بالتوتز و القلق أثثناء المو اقف الحساسة في المنافسة. & 9 \\
\hline$* . V \leqslant 0$ & أبذل كل جهدي مع الهنافس القوى. & 1. \\
\hline **.. & أُشعر أننى لا أنتنطيع إظهار قدر اتي ومهار اتي في المبار اة. & 11 \\
\hline$* . .711$ & أثنشعر التثاؤم قبل المباراة الحساسة. & it \\
\hline *.. V07 & كلما ذادت صعوبة الهنافسة كلما تحسن أدائي. & Ir \\
\hline$* . . \leqslant \wedge \varepsilon$ & لا أفقد الأمل عند نهاية المباراة عندما لا تكون النتيجة لصالحي. & $1 \varepsilon$ \\
\hline$* . .174$ & أففكر في احتمال أصابتى أثناء المباريات قبل أثشتر اكى في البطولة. & 10 \\
\hline$* .0 \ldots$ & في مباريات أخُرى فورمه جيدة و أدائي مرتفع فى بعض المباريات ومنخفض & 17 \\
\hline *. Vro & 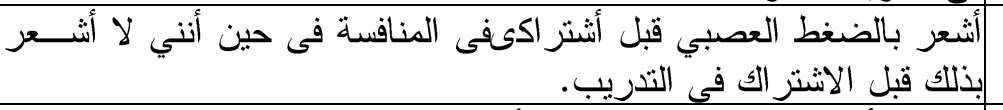 & IV \\
\hline$* .00 \leqslant$ & مستوى أدائى لا يتغير من مبار اة لأخرى. & 11 \\
\hline *. VOV & الثهامعة. أن أدائي يرتفع في المبار اة التي حضر فيهــا بعـضـ الثخصـــات & \\
\hline$* . .7 \varepsilon$. & بعد انتهاء المنافسة أثنعر أنه كان بإمكانى أن أكون في مستوى أفضل. & r. \\
\hline
\end{tabular}

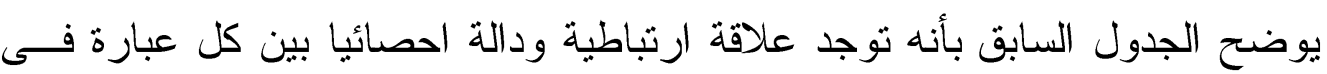

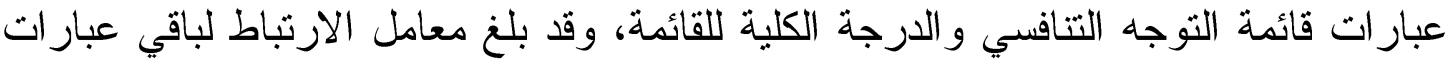

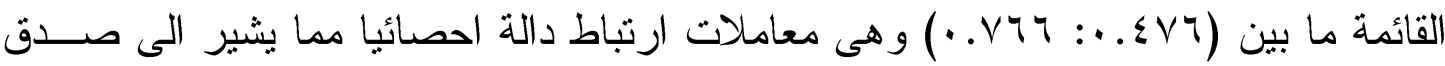

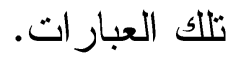


الثبات:

لحساب ثبات قائمة التوجه التتافسي قام الباحث بتطبيق القائمة على عينة عشو ائية من مجتمع البحث ومن غير عينة البحث الأساسية قو امها ( ع) وتم حساب معامل الفا كرونبــاخ

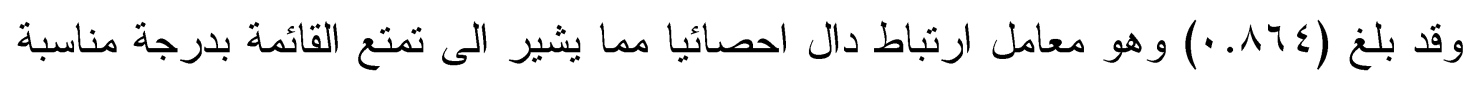
من الثبات.

التجربة الاستطلاعية:

قام الباحث باجر اء التجربة الاستطلاعية علي عينة قومها ( • ع) من لاعبي الكار اتيـــ خارج عينة البحث الاساسية لحساب المعاملات العلمية للمقياس البروفيل الانفعـالي للاعبـى الكار اتيه دن تصميم الباحث وقائمة التوجه التنافسي اعداد محمد حسـن عــلاوي (199 (م)

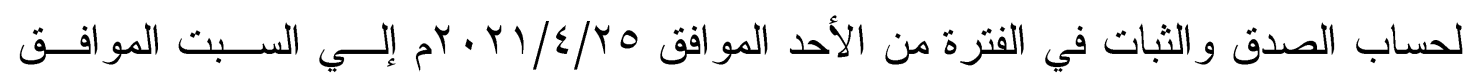

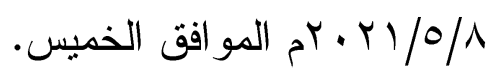
التجربة الاسناسية:

قام الباحث بإجر اء التجربة الأساسية وذلك بتطبيق أدوات جمع البيانـات (للمقيــاس

البروفيل الانفعالي للاعبى الكار اتيه من تصميم الباحث وقائمة التوجه التنافسي اعداد محمـــ

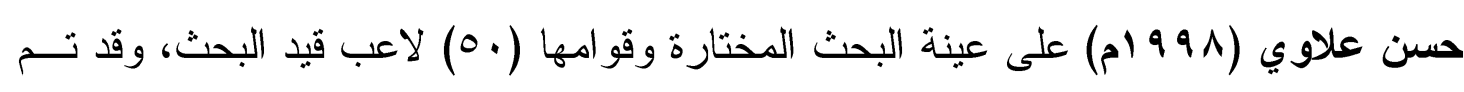

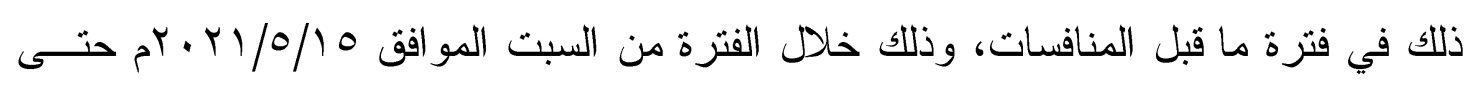

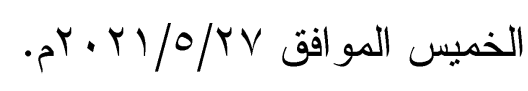
المعالجات الإحصائية: استخدم الباحث المعالجات الإحصائية المناسبة لطبيعة البحث وهي كما يلي: - المتوسط الحسابي. - الإنحر اف المعياري. - معامل الإزتباط "بطريقة بيرسون".

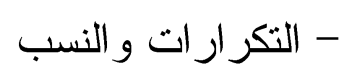

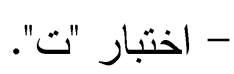




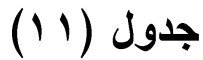

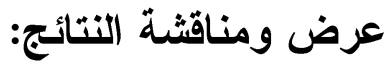

دلالة الفروق بين فى البروفيل الاففعالي وقائمة التوجه التنافسي وفقاللجنس(بنين وبنات) $(0 .=r=10)$

\begin{tabular}{|c|c|c|c|c|c|c|c|}
\hline \multirow{2}{*}{ قيمة } & \multirow{2}{*}{ المتوسطين } & \multicolumn{2}{|c|}{ بنات } & \multicolumn{2}{|c|}{ بنيزن } & \multirow{2}{*}{ الأبــــاد } & \multirow[b]{2}{*}{ م } \\
\hline & & $\varepsilon$ & ב & $\varepsilon$ & ב & & \\
\hline$\varepsilon . \wedge r$ & r... & T.O. & rq.£A & r.. 9 & $\varepsilon 1.04$ & التحكم الانفعالي & \\
\hline$\varepsilon .91$ & r. $\{r$ & r.VI & $\mu_{\Lambda} .00$ & T.T. & $\varepsilon . .9 V$ & تحمل المسؤولية & \\
\hline 1.99 & $1 . \Sigma V$ & r.10 & $r \Lambda . \leqslant 0$ & E.Y. & $r 9.94$ & الثقة بالنفس & 3 \\
\hline r.1r & r.IT & Y.VY & $r \cdot . \varepsilon$. & Y.V & r. T.Or & عدم التزدد & 恿 \\
\hline$r .09$ & Y.Y. & $\varepsilon .9 V$ & $\varepsilon 0 . r$. & 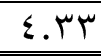 & $\leqslant V .0$. & الر غبة و التصميح & $\hat{t}_{1}$ \\
\hline$\{.07$ & $1 . . r V$ & 15.70 & 194.11 & IY... & r.Y. & إجمالى المقياس & \\
\hline V.\&. & $V .70$ & $7.1 \leqslant$ & $\lambda \mu .9 \Lambda$ & 0.11 & 91.74 & ال التنافس & 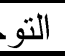 \\
\hline
\end{tabular}

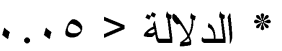

يوضح جدول (1) أنه توجد فروق ذات دلالة إحصائية فى منوسطات محاور مقياس

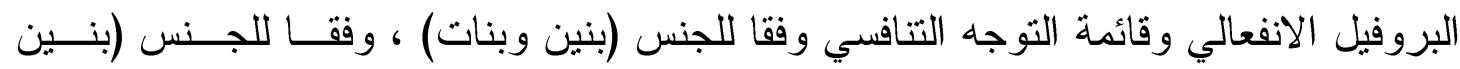

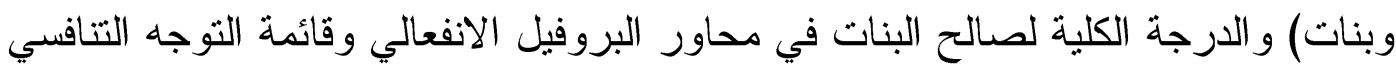
مناقشة نتائج الفرض الاول: وبالرجوع إلى جدول (1) (1) نجد أنه توجد فروق دالة إحصائياً بين أفراد عينة البحث

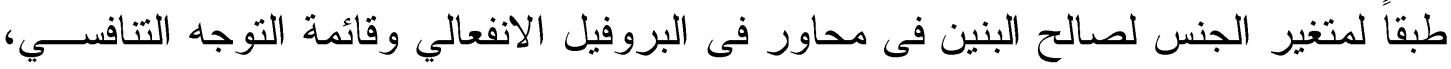

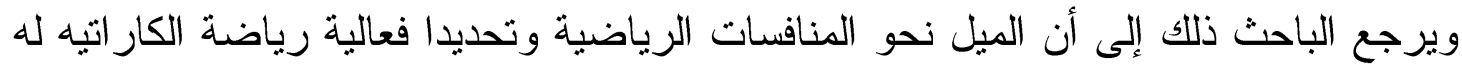

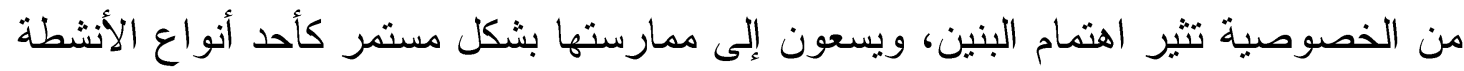

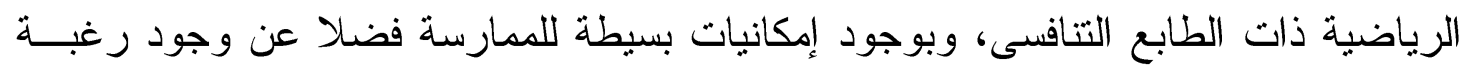

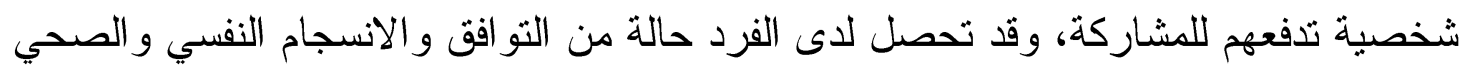

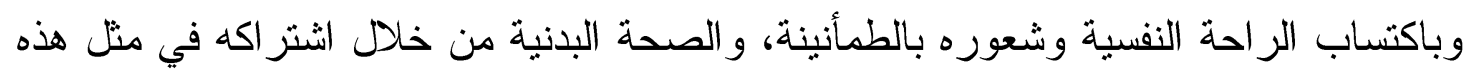

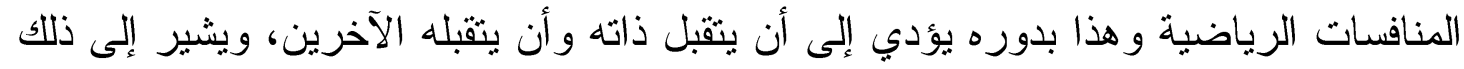

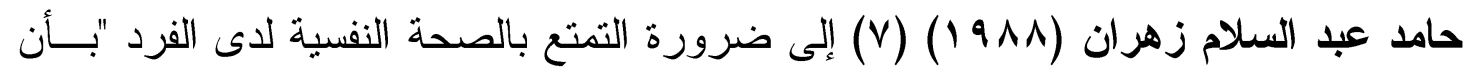

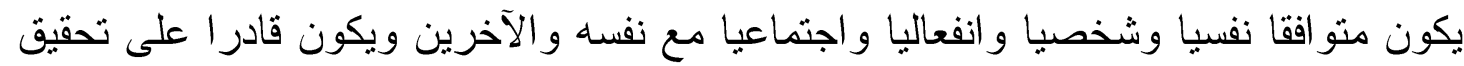

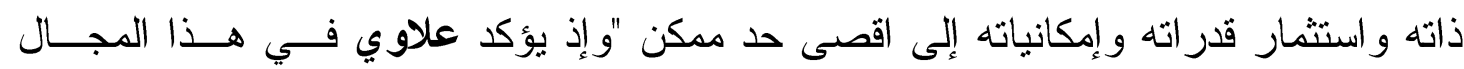

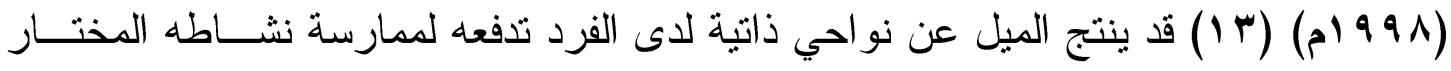

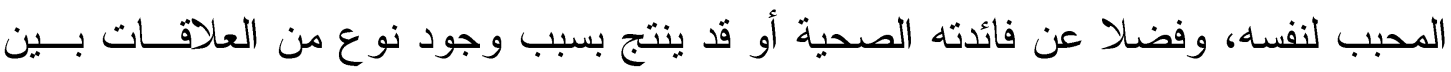
أصدقاء له يمارسون نفس النشاط ". 
وهذا ما يجيب عن الفرض الاول والأى ينص على؛ "توجد فروق دالة إحصائيا فـى

البروفيل الانفعالي و التوجه التتافسى بين لاعبي الكار اتيه وفقا للجنس".

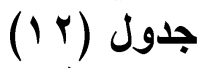

دلالة الفروق بين فى البروفيل الانفعالي وقائمة التوجه التنافسي وفقاً لنوع الاداء (كاتا-

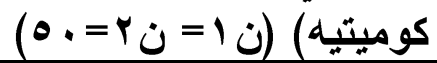

\begin{tabular}{|c|c|c|c|c|c|c|c|}
\hline \multirow{2}{*}{$\begin{array}{l}\text { قيمة } \\
\text { (ت) }\end{array}$} & \multirow{2}{*}{ المتوسطبل بينز } & \multicolumn{2}{|c|}{ لاعبي كوميتنيه } & \multicolumn{2}{|c|}{ لا عبي كاتا } & \multirow{2}{*}{ الأبـعـاد } & \multirow{2}{*}{ م } \\
\hline & & $\varepsilon$ & ح & $\varepsilon$ & م & & \\
\hline r.9r & $1 . V Y$ & r.OY & 19.70 & $\overline{r . Y T}$ & \&l.rv & التحكم الانفعالى & \\
\hline r... & 1.00 & Y.AV & rq.Yr & Y.A9 & $\varepsilon \cdot . Y \wedge$ & تحمل المسؤولية & \\
\hline$r .11$ & T.rT & $\varepsilon . \mu q$ & rA.VV & $r . \xi Y$ & $\varepsilon \cdot . \mu$. & التقة بالنفس ب . & \\
\hline r.9V & $r . . r$ & $\varepsilon \ldots 1$ & $\mu . . \leqslant 0$ & 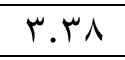 & Tr. & عدم التردد & 不 \\
\hline T.TS & r... & $\varepsilon .91$ & $\varepsilon 0 . \varepsilon$. & $\varepsilon . \mu V$ & $\varepsilon V . \varepsilon$. & الر غبة و التصميم & $=$ \\
\hline T.9 & $9 .+r$ & $1 \varepsilon . .1$ & 194.1. & $1 \cdot .17$ & r.1.Ar & إجمالى المقياس & \\
\hline$\varepsilon . .9$ & $\overline{\varepsilon . \vee \wedge}$ & $7.9 Y$ & 10.乏Y & 0.17 & q..r. & التوجه التتافسي & \\
\hline
\end{tabular}

يوضح جدول (r ( ) أنه توجد فروق ذات دلالة إحصائية فى متوسطات محاور مقياس

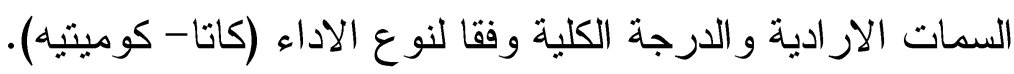

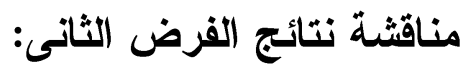

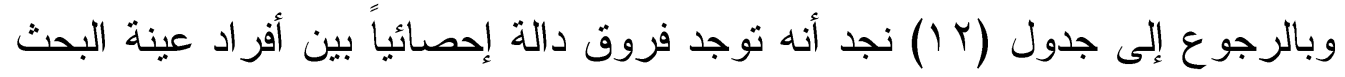

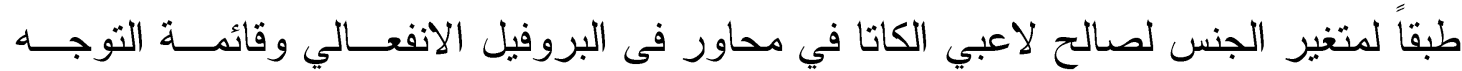
التنافسي

وتتقق نتائج هذه الدراسة مع دراسة سمير عبد الحميد (999 ا9م) (9) و التي قد تؤكد علي اهمية السمات الثخصية للاعبي رياضة الكار اتيه وان السمات الشخصية بالنسبة للاعبين

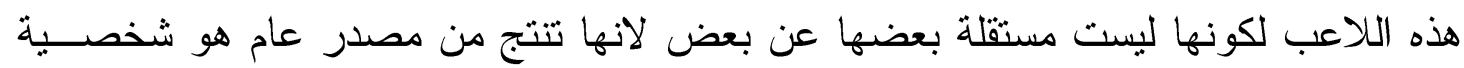

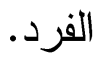

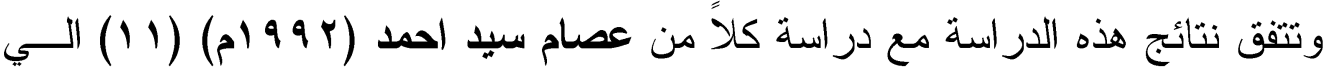

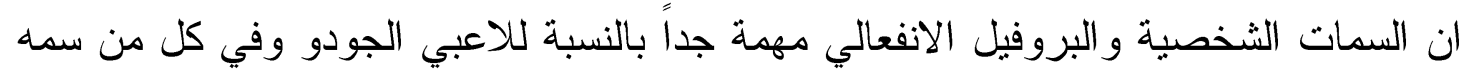
العصبية وسمه العدو انية وسمه الاكتئاب وسمه القابلية للاستثارة.

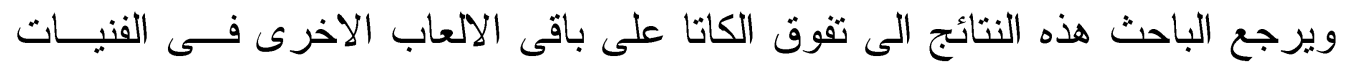

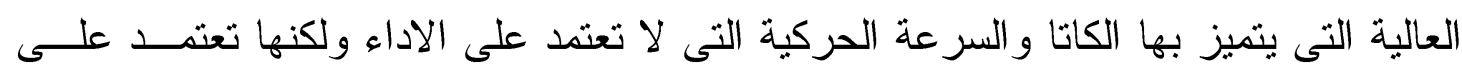

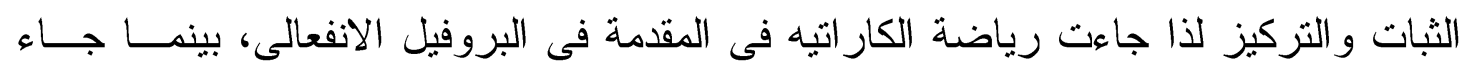

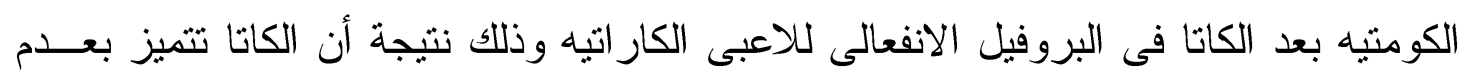
مجلة أسيوط لعلوم وفنوز التربية الرياضية 
بوجود اساليب الالتحام فى الاداء التى تتميز بالقوه والاداء الامتل وضعف نوعى فى البروفيل

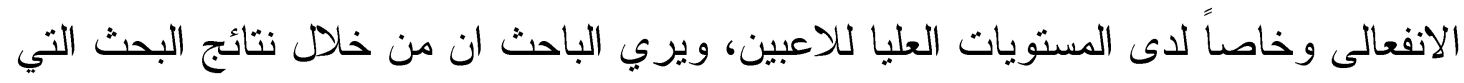

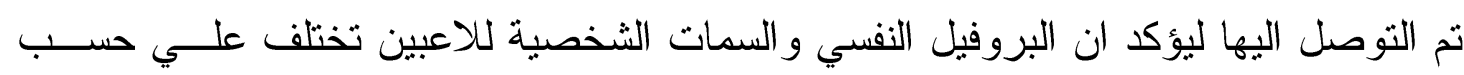

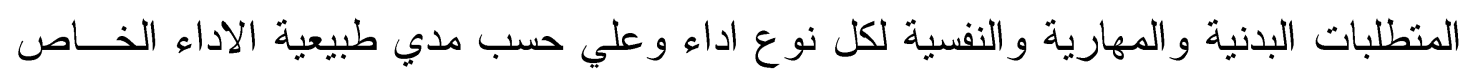
بكل رياضة.

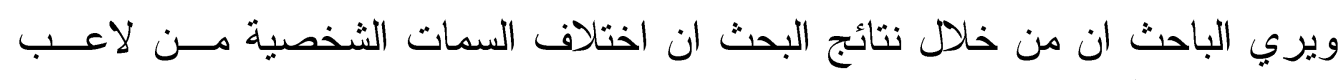

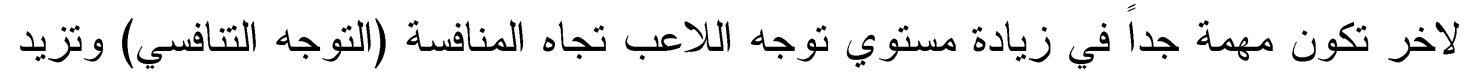

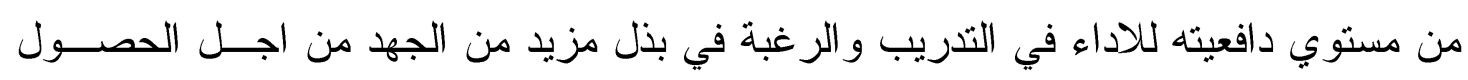

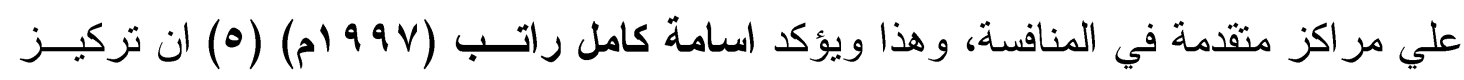

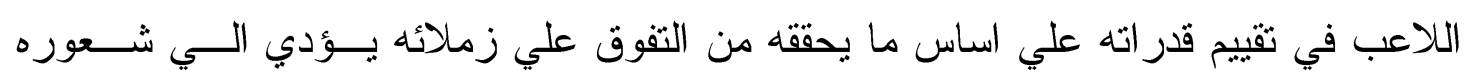

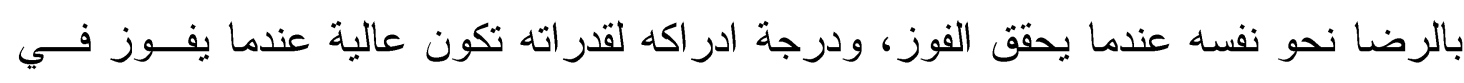

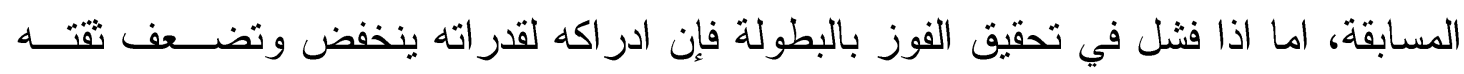

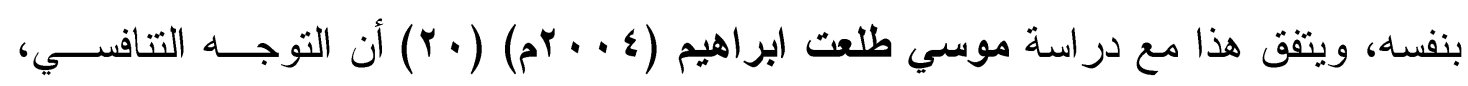

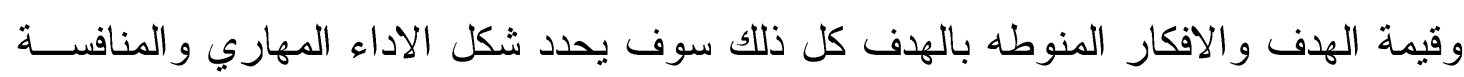
فيساعد علي الارتقاء بالمستوي التتافسي.

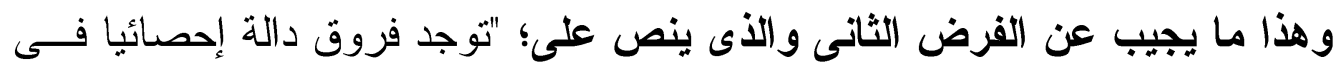

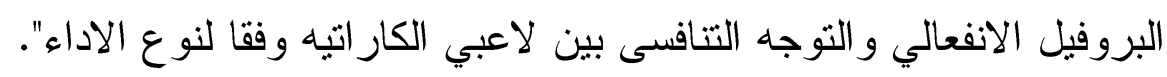

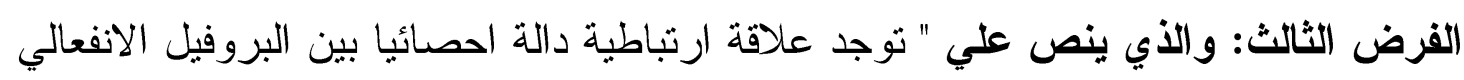

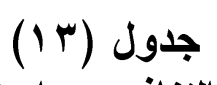
و التوجه التتافسي لاعبي الكار اتيه".

معامل الارتباط بين مقياس التوجة التنافسى وابعاد البروفيل الافعالى والارجة الكلية

$$
\text { ن }
$$

\begin{tabular}{|c|c|c|c|c|c|c|c|}
\hline الكارية & المسئولية & الرغبة & الانفعاليم & التردم & 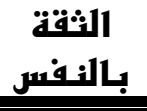 & |التصميم & السمات \\
\hline$\because A \cdot V$ & $* . . \Lambda V V$ & $* .79 \mathrm{~V}$ & $* . \vee \vee \wedge q$ & $* .70$. & $* . . \wedge \leqslant \Lambda$ & $* .71 \wedge 9$ & جه الند. \\
\hline
\end{tabular}

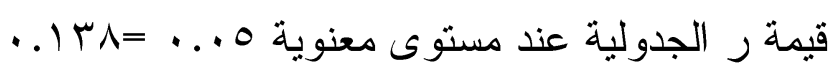

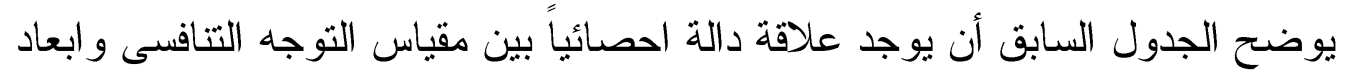
البروفيل الانفعالى للاعبى الكار اتيه و الدرجة الكلية. 


\section{or.}

ويرى الباحث أن ظهور هذه السمات لدى لاعب الكار اتيه نتيجة لأن رياضة الكار اتيه

من الرياضات التتافية التي دائمًا ما يكون التوجه التتافسي للمشاركين فيها توجهًا نحو النتيجة

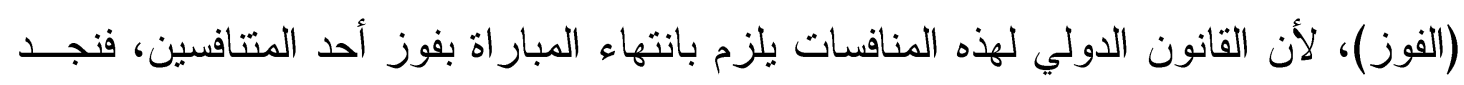
معظم الاعبين يضعون لأنفسهم أهدافًا تركز على الفوز للحصول على أحد المر اكز المتقدمـة

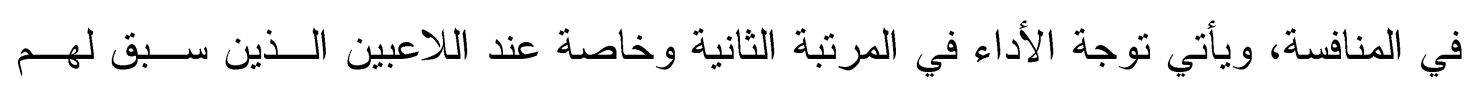
الاشتر الك في المنافسات فيمثل ذلك ضغطاً كبيرًا عليهم لإثبات وجودهم الفني بـين اللاعبـين المشهورين سعيًا ور اء تحقيق الشهرة.

حيث بشير كل من "حسن أبو عبده (ع 99 (م)، حسـن عـلاوي (Y . . rم)، صسـلاح

السقاء" (^ . . بم) إلى أن التوجه التتافسي نحو النتيجة يظهر عند اشتر الك اللاعب في المنافسة الرياضية بهدف الفوز بالميداليات و التغلب على منافسيه ومحاولة مقارنة مســتو اه بــالآخرين وتجنب الهزيمة بقدر الإمكان، كما يظهر التوجه التتافسي نحو الأداء عندما يرتبط بمحاولــة اللاعب الاشتر الك في المنافسة واضعًا نصب عينه تطوير مستو اه وتحسنه عن الأداء الســابق له، وبذل أقصى جهد ممكن و إظهار أكبر قدر من قدراته دون أن يرتبط ذلك بمقارنة مســتو اه بمستوى الآخرين ولكن بهدف تطوير أدائه في ضوء مستوياته الســابقة، وبالتــالي شـــوره بالنجاح في حالة تحقيق ذلك وشعوره بالفشل عندما بخفق في تحقيق هدفه بصرف النظر عن

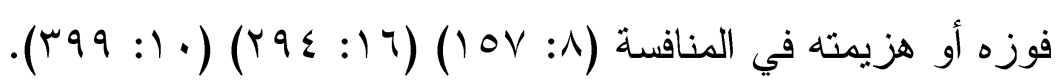

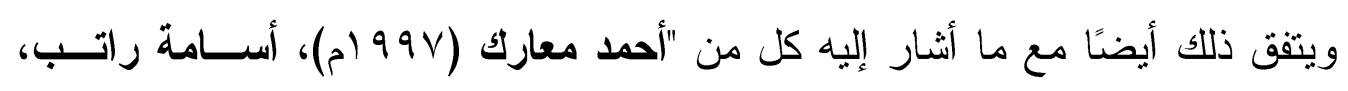
إبراهيم خليفة، منى المرسي" (r . . rم) إلى أن اللاعب الذي يركز على أهداف إنجاز النتائج

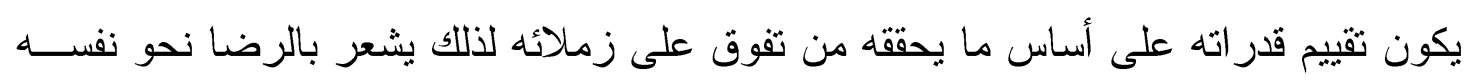

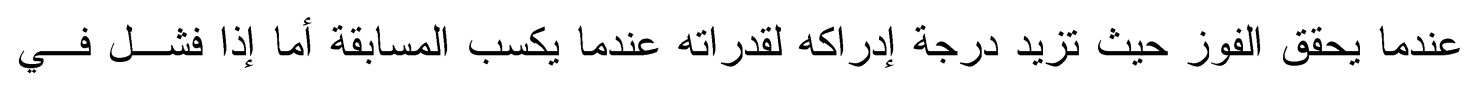

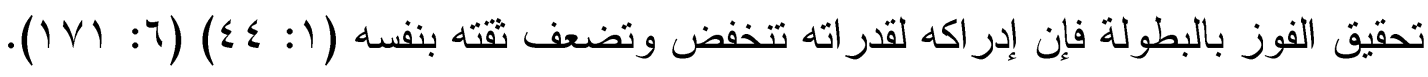
ويرجع الباحث هذه النتائج الى أن البروفيل الانفعالي للاعبى الكار اتيه له ارتباط وثيق

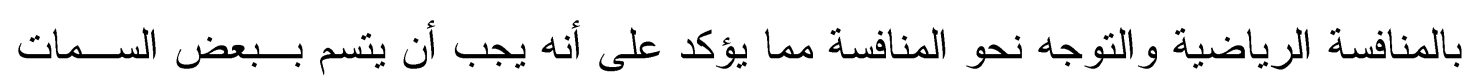
الانفعالية الإيجابية حتى يستطيع أن يتحكم في انفعالاته.

وهذا ما يجيب عن الفرض الثالث والذى ينص على؛ "توجد علاقة ارتباطيــه دالــة إحصائيا بين البروفيل الانفعالي والتوجه التنافسى لاعبي الكاراتيه". 
الاستنتاجات:

1- توصل الباحث الى مقياس البروفيل الانفعالى للاعبى الكار اتيه مكون من خمســة ابعـاد

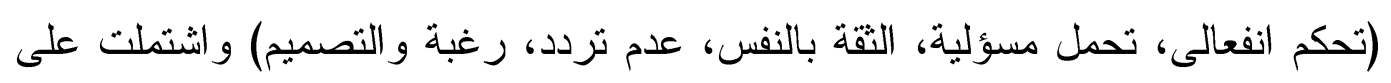

9

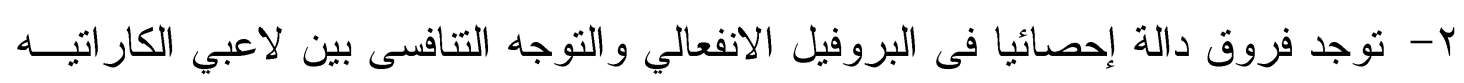
وفقا للجنس.

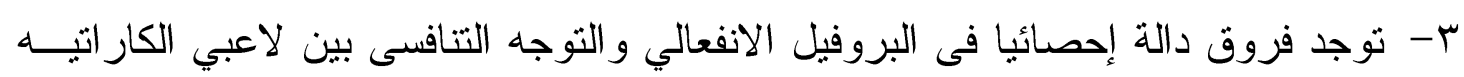
وفقا لنوع الاداء.

ـ - توجد علاقة ارتباطيه دالة إحصائيا بين البروفيل الانفعالي و التوجـهـ التتافسـى لاعبـي الكار اتيه قبد البحث.

التوصيات:

1- الاهتمام بالدورات التثقيفية و التدريبية للاعبين و المختصين لاطلاعهـم علـى البحــوث النفسية وذلك للتنريب على تعليم المدربين كيفية مواجهة الظروف المحيطة ومواجهتها. r- عمل برامج تتمية بشرية تساعد الاعبين على أعادة النظر فيما يعتقدونة من أفكار سلبية عن قدر اتهم و التى قد لايكون لها أساس من الصحة.

r- الاستعانة بالمتخصصين فى الجانب النفسي للاعبين لحل المشكلات النفسية التي يو اجهـانها. اللاعبين قبل و اثثاء المنافسه.

ع - اهتمام وسائل الإعلام بالاداء الجيد للاعبين الكار اتيه و العمل على نشر الرياضـــة بــين

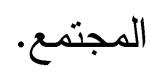

0- إجر اء أبحاث علمية مشابهة لتطوير الجانب النفسي الاعبين.

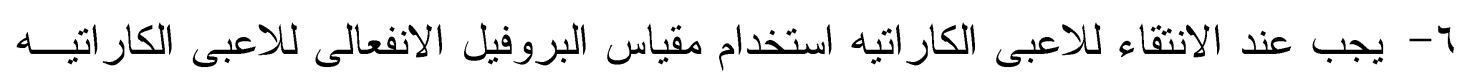
قبد البحث. V- يجب على المدرب التعرف على مستوى التوجه التتافسى للاعبين كأحد أساليب الرعايــة النفسية. 


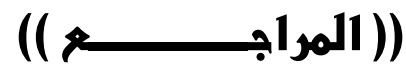

أولاً: المراجم العربية:

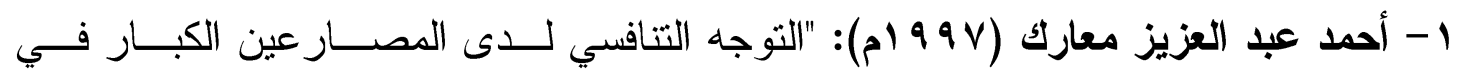
جمهورية مصر العربية"، بحث منشور، المؤتمر العلمي الرياضة وتحديات

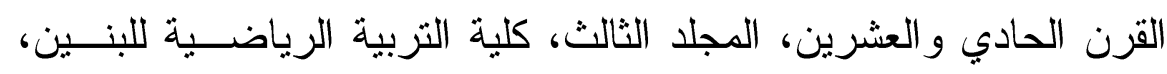

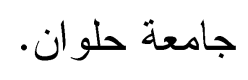

r- أسامة عبد الرؤوف أحمد (1 . . rم): وجهه الضبط و علاقتها بالبروفيل النفسى الانفعالى

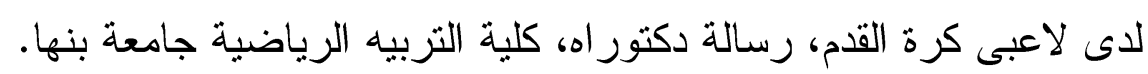

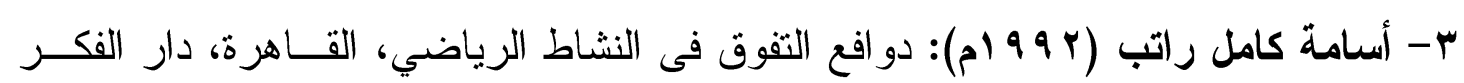
العربي.

ع - أسامة كامل راتب (099 (1م): علم النفس الرياضي، المفاهيم، التطبيقات، ط؟، دار الفكر العربي، القاهرة.

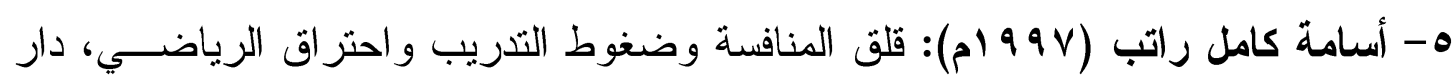
الفكر العربي، القاهرة.

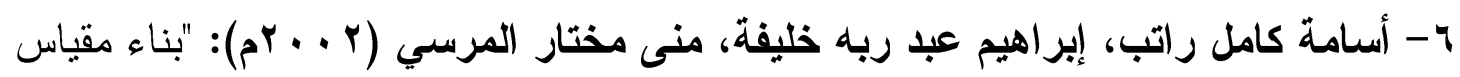

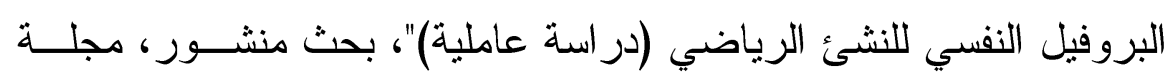

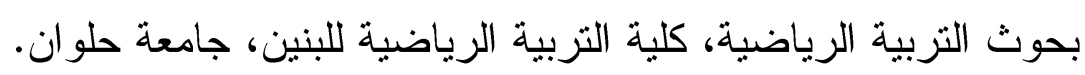

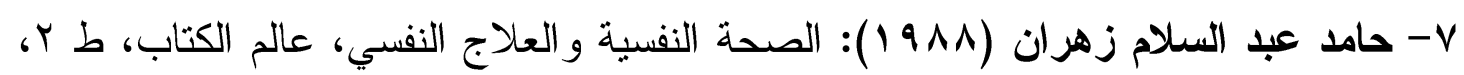

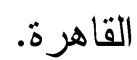

^- حسن حسن عبده (ع 9 (1)): "التوجه التتافسي لدى الرياضيين من فرق الدرجة الأولـى لـى

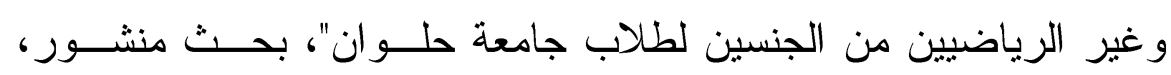

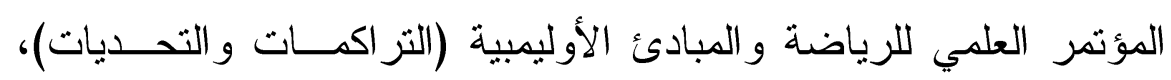

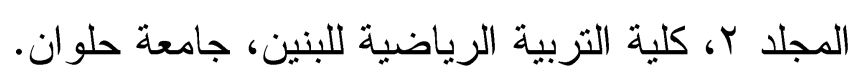

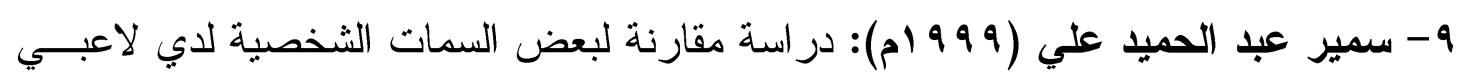

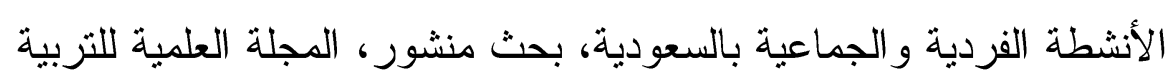

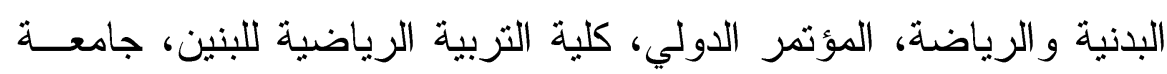

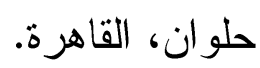


• 1- صلاح بن أحمد السقاء (^ . . rم): "دراسة المهارات النفسية المحددة للتفوق الرياضي

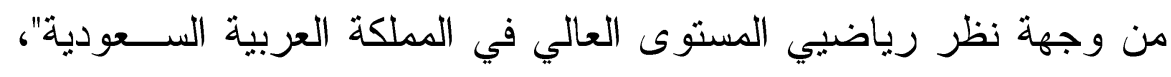

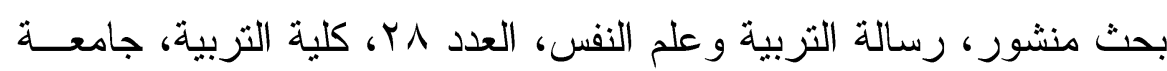
الملك سعود.

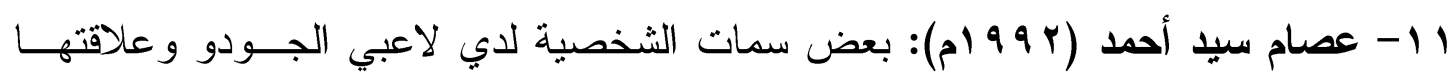

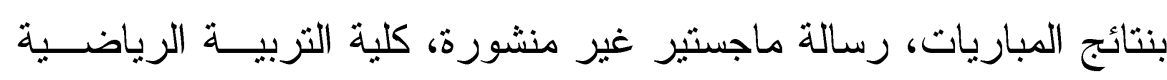

$$
\text { للبنين، جامعة حلو ان، القاهرة. }
$$

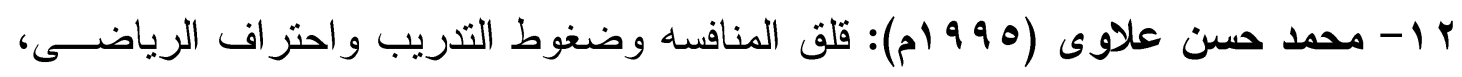

$$
\text { دار الفكر العربى، القاهره. }
$$

ب ا - محمد حسن علاوى (99191م): مدخل فى علم النفس الرياضى، مركز الكتاب للنشــر، القاهره.

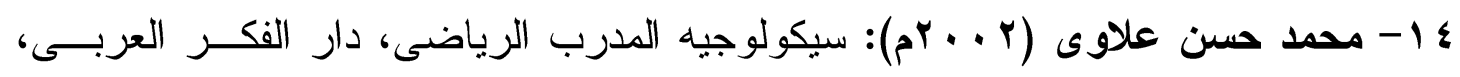
القاهره.

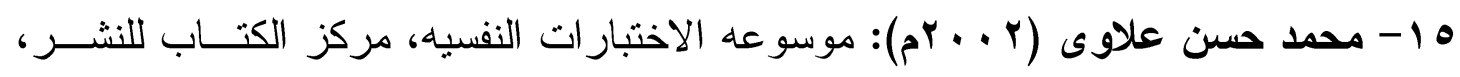

$$
\text { القاهره. }
$$

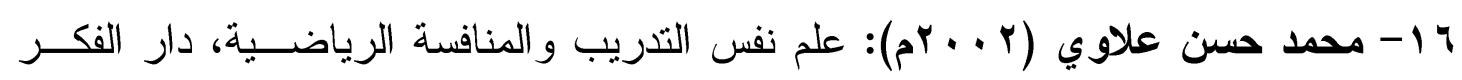

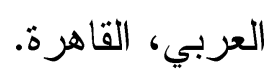

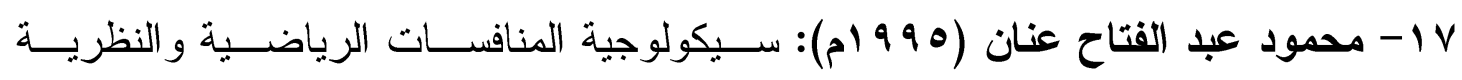

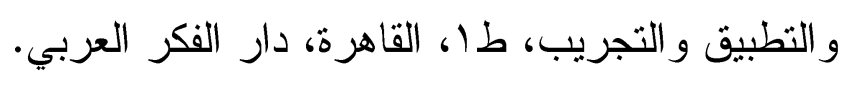

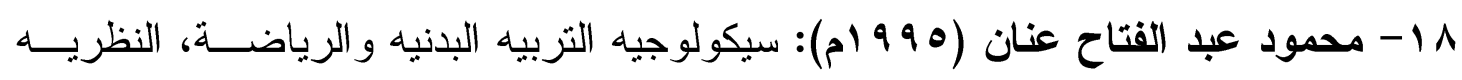

$$
\text { و التطبيق و التجريب، دار الفكر العربى، القاهره }
$$

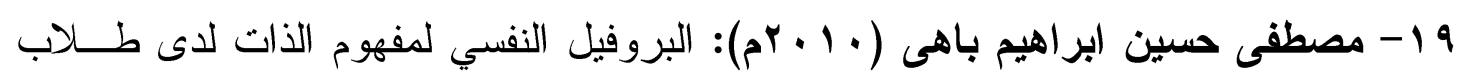

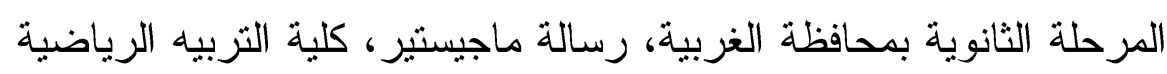

$$
\text { للبنين بالهرم، جامعة حلوان }
$$

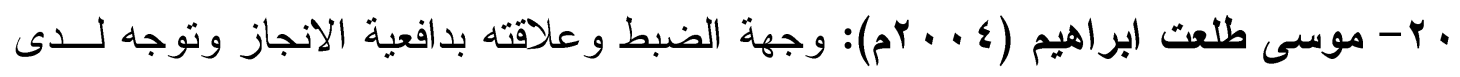

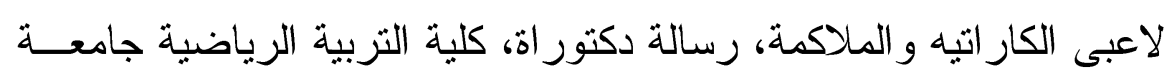

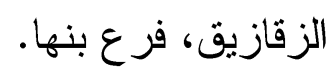




\section{OY}

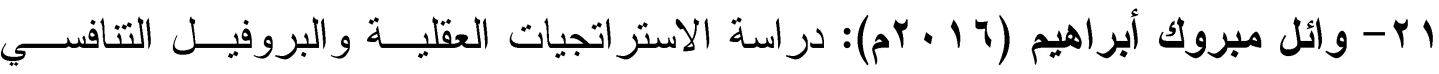

لملاكمي الشباب و علاقتهم بمستوى فاعلية الأداء المهاري: دراسة تطبيقية

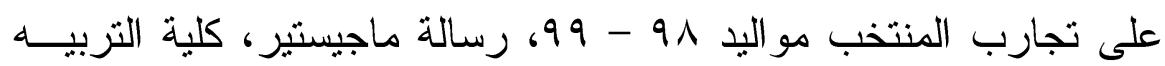

الرياضية للبنين بالهرم، جامعة حلوان.

r r - يحي النقيب ( •99 (م): علم النفس الرياضي، اللجنة السعودية للتربية الرياضية، معهد إعداد القادة.

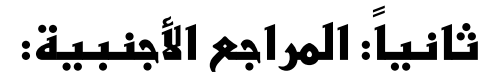

23- Gat, 1 \& Mc. Writer, B (1998): Personality characteristics of competitive and recreation cyclists, Journal of sport behavior (Mobile, ALA) 21(4), Del PP. 408-420, Refs: 29.

24- Rainer martens \& robins vealey bamon burton (1997): competitive anxiety in sport. Illinois human kinetics books. page 14 